\title{
The Needy Donor: An Empirical Analysis of India's Aid Motives
}

\author{
Andreas Fuchs ${ }^{\mathrm{a}}$ \\ Krishna Chaitanya Vadlamannati ${ }^{\mathrm{b}}$
}

June 2012

\begin{abstract}
It is puzzling that India, which has a large domestic constituency of people suffering from underdevelopment, chronic poverty and mal-governance, is emerging as an important aid donor. With the intension of learning why poor countries provide foreign aid, this article is the first to econometrically analyze India's aid allocation decisions. First, we utilize cross-sectional data on aid commitments by the Ministry of External Affairs to 125 developing countries, obtained in US dollars from AidData for the 2008-2010 period. Second, we compare India's bilateral aid allocation with that of other donors. Our findings show that India's aid allocation is partially in line with our expectations of the behavior of a "needy" donor. Commercial and political self-interests dominate India's aid allocation. The importance of political interests is found to be significantly larger for India than for all DAC donors. Moreover, we find that countries which are closer geographically are favored, and that countries at a similar developmental stage are more likely to enter India's aid program.
\end{abstract}

Key words: Foreign aid, new donors, aid allocation, South-South Cooperation, India.

JEL classification: F35

\begin{abstract}
Acknowledgements: This research is part of the project "Foreign Aid of Emerging Donors and International Politics" supported by the Deutsche Forschungsgemeinschaft (DR 640/4-1). We further thank the Göttingen Graduate School of Social Sciences (GGG) for financial support. We also thank Axel Dreher, Nils-Hendrik Klann, Stephan Klasen, Hannes Öhler, Devesh Roy and Rainer Thiele and participants at the 2011 PEGnet conference in Hamburg, Germany, at the Ph.D. Colloquium of the German Development Institute (DIE) in Bonn, Germany, at the seminar of the "Verein Freiburger Wirtschaftswissenschaftler e.V." at University of Freiburg, Germany, at the Development Economics Research Group Seminar at University of Goettingen, Germany, at the Second World Congress of the Public Choice Societies in Miami, U.S.A., and at the Annual Convention of the International Studies Association in San Diego, U.S.A., for useful comments on earlier drafts of this work. Excellent research assistance was provided by Jiaqi Ji and Jan Paulick, who supported us with the construction of the databases on Indian development assistance. We thank Scott Jobson for his proof-reading of an earlier version of the paper, as well as for supporting us with the construction of the database on Commonwealth membership.

${ }^{a}$ Heidelberg University, Alfred-Weber-Institute for Economics, Bergheimer Strasse 58, 69115 Heidelberg, Germany, University of Goettingen, Germany, e-mail: mail@andreas-fuchs.net.

${ }^{\mathrm{b}}$ Heidelberg University, Alfred-Weber-Institute for Economics, Bergheimer Strasse 58, 69115 Heidelberg, Germany, University of Goettingen, Germany, e-mail: krishna.vadlamannati@awi.uni-heidelberg.de
\end{abstract}




\section{Introduction}

India, widely seen as one of the success stories of globalization, has significantly accelerated its economic growth since the inception of economic reforms in 1991 (Basu and Maertens 2007; Basu 2008; Panagariya 2010). The country is one of the fastest growing economies in the world and host to some of the largest foreign investment inflows in recent years (UNCTAD 2010). Yet, for many, India's progress since its independence 65 years ago is disappointing. Despite rapid economic growth over the last decade, some areas in India continue to be severely underdeveloped (Banerjee 2010). India has a large domestic constituency of people suffering from underdevelopment, chronic poverty and mal-governance. According to the World Bank's (2011) estimates, 37\% of the Indian population is below the poverty line of US\$ 1.25 a day. Moreover, India ranks below its neighbors Bangladesh, Bhutan, Nepal, Pakistan and Sri Lanka in terms of life expectancy, access to sanitation, infant immunization, and underweight children. It also ranks below Bangladesh, Bhutan and Sri Lanka in controlling the infant mortality rate (Dreze and Sen 2011), below Sri Lanka in terms of the literacy rate and access to education (UNESCO 2011), below Nepal in the 2011 Global Hunger Index (GHI 2011), and below Bangladesh with respect to controlling literacy among female youths (Dreze and Sen 2011).

Therefore, it is not surprising to note that despite its rapid economic growth in recent years, India is still one of the recipients of development aid. In 2009, the total net official development assistance received by India from all donor countries was about US\$ 2.502 billion, of which US\$ 1.578 billion was in the form of net bilateral aid flows from countries organized in the Development Assistance Committee (DAC) (OECD 2012). ${ }^{1}$ At US\$ 630 million, India is still the single largest recipient of development aid from the United Kingdom (OECD 2012). That being said, it is puzzling to note that India itself is an aid donor. ${ }^{2}$ In fact, Indian engagement in delivering foreign aid goes back to the $1950 \mathrm{~s}$, with its primary target being to provide development assistance to neighboring countries. Traditionally, Indian foreign aid has focused on technical assistance. Ever since it began in 1964, the Indian Technical and Economic Cooperation (ITEC), India's flagship external assistance program, has provided training,

\footnotetext{
${ }^{1}$ Moreover, India also receives a substantial amount of aid from international NGOs. For example, in 2010, the Bill \& Melinda Gates Foundation committed US\$ 100 million to India (OECD 2012).

${ }^{2}$ Note that India avoids the term 'donor'. It rather perceives itself as a partner in South-South cooperation (see Chaturvedi 2008 for a discussion).
} 
education and technical expertise to about 40,000 NGO personnel, scholars and leaders from developing countries (Agrawal 2007).

Over the last few years, aid from India has diversified and gained prominence. During the economic reforms period spanning from 1992 to2009, official foreign assistance provided under the umbrella of the Ministry of External Affairs (MEA) amounted to INR 18,950 crores (US\$ 4,473 million) according to its annual reports (MEA 1993-2010). The Ministry allocated INR 2359 crores (US\$ 444 million) to aid-related activities in the 2009 financial year alone (MEA 2010). According to Manning (2006: 375), India, together with China, is one of the two 'heavyweights' among the non-DAC donors. India's increased commitment to providing development aid is reflected in the government's decision to setup a separate agency by 2012 in order to oversee the aid allocation process (Patel 2011).

In contrast to the extensive empirical literature on the allocation of development aid from Western donor countries (e.g., Alesina and Dollar 2000), studies on development assistance provided by non-DAC donors lack rigorous empirical analysis. Notable exceptions are Neumayer (2003a, 2004) on Arab aid, Dreher and Fuchs (2011) on China's foreign assistance, and Dreher et al. (2011) on aid from donors outside the DAC in general (excluding India). ${ }^{3}$ Concerning India's foreign aid in particular, to the best of our knowledge, no prior study provides an econometric analysis of the determinants of India's aid allocation decisions. This paper aims to fill this gap in the literature. A better understanding of the factors driving India's aid allocation decisions may offer important insights into why poor countries serve as donors of foreign aid to other developing countries.

India claims that its aid is more need-oriented than aid from richer donor countries as its economic and political structure is closer to that of other developing countries. If this is the case, India should provide more aid to countries that are closer to India in terms of economic development. We test this prediction empirically. At the same time, many suspect that India might be increasingly using foreign aid as an instrument to gain access to overseas markets for its goods and services, pave the way for Indian investment abroad, and secure access to natural resources (e.g., Agrawal 2007; Kragelund 2008). Another argument put forward is that Indian

\footnotetext{
${ }^{3}$ Given that India is poorer in terms of income per capita than any of the donors covered in Dreher et al. (2011), India serves as an excellent case to study the behavior of "needy" donors.
} 
aid is extensively used as a foreign policy tool to expand the country's geopolitical and diplomatic influence (e.g., Agrawal 2007). The consensus in the literature is that political and commercial interests are important determinants of aid allocation for the DAC group of "rich" donors (e.g., Alesina and Dollar 2000; Neumayer 2005; Kuziemko and Werker 2006), as well as for multilateral organizations (e.g., Kilby 2006; Dreher et al. 2009). Not only do we also expect to find this for the "needy" donor India, we expect these relationships to be even more pronounced. We argue that India has more incentives to provide politically and commercially motivated aid since the country lags behind DAC donors in terms of economic development. We will elaborate this hypothesis below and test it empirically.

Our findings show that India's aid allocation is partially in line with our expectations of the behavior of a "needy" donor. Commercial and political self-interests dominate India's aid allocation. The importance of political interests, proxied by the voting alignment between donor and recipient in the United Nations, is found to be significantly larger for India than for all DAC donors. Moreover, we find that countries which are closer geographically are favored by the "needy" donor and that countries at a similar developmental stage are more likely to enter India's aid program.

The paper is structured as follows. Section 2 introduces India's foreign aid program and examines its evolution over time. Based on the previous aid literature, Section 3 develops our hypotheses on the aid allocation behavior of a "needy" donor. In Section 4, we empirically analyze the determinants of aid allocations by the MEA based on data for the years 2008-2010 from AidData, a project-level database (Findley et al. 2009). To analyze whether Indian aid is special, we further compare India's aid allocation decisions with those of other donors. In particular, we test whether Indian aid is motivated to a higher extent by political and commercial considerations and to a lesser extent by recipient needs compared to aid from "rich" donors. Finally, Section 5 summarizes our results, concludes, and provides policy implications.

\section{An Overview of India's Aid Program}

The origins of Indian development aid date back to the Colombo Plan of 1950, which was formulated in Sri Lanka by a group of Commonwealth countries (including India) with the objective of providing assistance to developing countries in order to raise their respective living 
standards. Along with the Colombo Plan, India started providing aid in the form of grants and loans. India's primary target in its early days after independence was to support neighboring countries, in particular Bhutan, Myanmar, and Nepal. ${ }^{4}$ However, despite its active role, Indian development aid largely remained confined to the field of technical assistance, mainly due to resource scarcity and strong demand for developmental funds within the country. ${ }^{5}$ As a founding member of both groups of states, India's aid program was anchored in the Non-Aligned Movement and the Group of 77 at the United Nations.

After the collapse of the USSR and a severe balance-of-payments crisis, India introduced pro-market economic reforms in 1991. Eventually, as the economy grew stronger, India deepened its engagement with developing countries and extended its aid program. The 2003-04 budget speech is considered as a sharp break in India's role as an actor in international development cooperation. India wanted to be perceived primarily as an aid donor and not as a recipient of foreign assistance. Following the speech, India announced several key changes to its development cooperation (e.g., Price 2004). First, the country would only accept government-togovernment aid that is untied and provided by five selected countries or the European Union. Second, India would repay its debt to most of its bilateral donors and multilateral institutions. Third, it would extend its own aid effort to other developing countries through debt cancellations for some Highly Indebted Poor Countries, and an increase in its grant and project assistance under the so-called India Development Initiative. Although the actual policy changes were softer in the beginning than the speech seemed to imply (see Price 2004 for a discussion), it became clear that India intended to play an important role in the world of international development cooperation. The provision of credit lines via India's Exim Bank is one of the most prominent outcomes of these reforms.

To provide a better understanding of how India's aid program evolved over time, we compiled data on India's aid budget since 1966 based on the annual reports of the Ministry of External Affairs (MEA 1967-2011). This information needs to be interpreted with caution

\footnotetext{
${ }^{4}$ For 1958, Chanana (2009) highlights Indian aid commitments of about Rs. 100 million (US\$ 21 million) in multiyear grants to Nepal, Rs. 200 million (US\$ 42 million) to Myanmar, and the financing of 60\% of Bhutan's budget. ${ }_{5}$ According to Dutt (1980), a total of 1,442 people received technical training in India under the Colombo Plan up until 1960. According to the Colombo Plan Reports (as cited in Dutt 1980), this number increased to 3,550 between 1961 and 1971.
} 
because of significant changes over time in the way the ministry categorizes its aid amounts. ${ }^{6}$ Apart from that, note that the data exclude aid flows from institutions other than the MEA. Moreover, we lack detailed information on which fraction of the calculated aggregated aid values satisfy the OECD's definition of Official Development Assistance (ODA). ${ }^{7}$ Nevertheless, the figures should provide the reader with an intuition of the overall evolution of the size of India's aid program. As can be seen from Figure 1, there is a spike in India's aid budget in $1972 .{ }^{8}$ This is largely due to the additional external assistance provided by India to Bangladesh, which obtained independence from then West Pakistan (now Pakistan) in 1971 with the help of India. According to the MEA annual report in 1973, India allocated about 191.5 crores Indian rupees (about US\$ 422.5 million in 2000 constant prices) of aid (mostly in the form of grants and concessional loans) to Bangladesh in 1972.

India's aid disbursements suffered a large decline during the early 1990s, a period marred by balance-of-payments problems and political crises. However, from the mid-1990s onwards, there has been a surge in disbursements of development aid. Though there were ups and downs, which could be attributed to political instability in the 1990s and to the Global Financial Crisis starting in 2008, India's aid budget shows an increasing trend during the economic reforms period that started in 1991. More precisely, India's aid budget rose from 13.4 crores Indian rupees (about US\$ 40.3 million in constant 2000 prices) in 1966, to 2,917.4 crores Indian rupees (US\$ 362.8 million in constant 2000 prices) in 2010, which is roughly $0.04 \%$ of India's GDP. This amount, which only captures MEA aid, is comparable to Austria's total ODA (US\$ 395.2

\footnotetext{
${ }^{6}$ Values for grant-in-aid to the Indian Council of Cultural Relations and support to the African National Congress are excluded from our analysis. See Agrawal (2007) for a discussion of limitations of the use of data from MEA annual reports as a proxy for India's aid budget.

${ }^{7}$ Note that the DAC defines ODA as financial flows to developing countries provided by official agencies with the objective to promote economic development and welfare, and that contain a grant element of at least $25 \%$ (see http://www.oecd.org/dataoecd/26/14/26415658.PDF, accessed August 2011). Although we lack detailed information on the concessionality of each individual loan, it seems that aid provided by the MEA by and large qualifies as ODA. According to a study by ECOSOC (2008), 80\% of India's total aid disbursed is grants. The remaining fraction is loans with an estimated grant element of $53-57 \%$.

${ }^{8}$ Using data on India's GDP deflator and exchanges rates obtained from the World Development Indicators (available at http://databank.worldbank.org, accessed May 2012), we converted all aid values from Indian rupees in current prices to constant 2000 US\$.
} 
million in constant 2000 prices) and amounts to about two thirds of Italy's total bilateral ODA (US\$ 547.0 million in constant 2000 prices). ${ }^{9}$

In addition to the MEA, India provides concessional finance via its Export-Import (Exim) Bank. The sum of all financial flows provided by the Exim Bank between 2005 and 2009 and registered on AidData (Findley et al. 2009) amounts to US\$ 2.45 billion (in constant 2000 prices). In contrast to MEA aid, the largest share of Exim Bank loans (73.2\%) was allocated to Sub-Saharan African countries. Although Sinha and Hubbard (2011) find that most credits satisfy the criteria of a grant element of at least $25 \%$, they conclude that Indian LOCs do not qualify as ODA as defined by the OECD. Since the credit lines are extended for the purpose of export promotion, these flows meet the criteria of officially supported export credits instead. ${ }^{10}$ Therefore, we restrict our empirical analysis below to cover financial flows provided by the MEA only.

\section{Theory and Hypotheses}

The extensive literature on the allocation of development aid emphasizes that aid from Western donors and multilateral institutions is guided by strategic interests, in addition to economic needs in developing countries (Alesina and Dollar 2000; Kuziemko and Werker 2006; Dreher et al. 2009; Kilby 2009a). In contrast, research on non-DAC aid is still in its infancy. Manning (2006), ECOSOC (2008) and Kragelund $(2008,2010)$ provide good overviews of the aid activities of these so-called new donors. Among the few econometric studies on aid allocation by non-DAC donors are Neumayer (2003a, 2004) on Arab aid, Dreher and Fuchs (2011) on China's foreign assistance, and Dreher et al. (2011) on aid from donors outside the DAC in general. The literature usually groups the determinants of a donor's aid allocation into three categories. First, aid allocation follows recipient needs. Based on humanitarian motives, altruist countries provide more assistance to poorer countries. An important goal is poverty reduction. Second, aid is allocated based on good policies. Following the idea of merit, countries with good policies and

\footnotetext{
${ }^{9}$ A comparison with the non-DAC donors covered in Dreher et al. (2011: 1952) underlines that India is one of the most important providers of development assistance outside the DAC.

${ }^{10}$ According to Sinha and Hubbard, the grant element varies between $41.25 \%$ for Heavily Indebted Poor Countries (HIPC) and $17.11 \%$ to $24.56 \%$ for middle income countries with medium to high levels of debt.
} 
good institutions are supported through increased aid flows. Third, donors' aid patterns are shaped by political and commercial self-interests. In the following, we discuss whether and how these motives are reflected in India's aid policy.

Referring to the role that Indian values might play in India's aid provision, Meier and Murphy (2011: 7) point out that, "Hinduism, Buddhism, Islam and Sikhism all espouse solidarity with the suffering and giving without expectations for return." In line with this, the Indian government claims that its aid program indeed responds to the economic needs of developing countries. For example, the MEA describes the ITEC program as "an earnest attempt by India to share the fruits of its [i.e., India's] socio-economic development and technological achievement with other developing countries" (ITEC 2011). According to Banerjee (1982: 27), India provides aid to neighboring countries "with the sole objective of restoring the local citizens to a place of primacy." If this is the case, India's aid should be targeted to needier countries. ${ }^{11}$ We test the following hypothesis:

Hypothesis 1a: India's aid allocation responds to the economic needs of developing countries.

In this regard, Banerjee (1982: 55) claims that India's aid is particularly need-oriented since it provides the "appropriate technology and managerial experience" to other developing countries. He argues that India's aid is more need-oriented than aid provided by "rich" donors as its economic and political structure is closer to that of other developing countries. Similarly, the Indian MEA claims that it "possess[es] skills of manpower and technology more appropriate to the geographical and ecological conditions and the stage of technological development of several developing countries." 12 If we take this argument at face value, this implies that India should allocate more aid to countries that are at a similar stage of development. Consequently, aid from India should decrease with a recipient country's distance to India's own development level. We will test the following hypothesis:

Hypothesis 1b: The "needy" donor India allocates more aid to countries at a similar stage of development.

\footnotetext{
${ }^{11}$ Dreher et al. (2011), in turn, find that non-DAC donors care less for recipient need than traditional DAC donors. Note, however, that their study excludes aid from India.

${ }_{12}$ Quoted on several websites of Indian embassies, e.g., the Indian embassy in Azerbaijan: http://indianembassybaku.org/en/8/ (accessed: February 8, 2012).
} 
At the same time, India emphasizes that its aid serves "mutual benefit" (ITEC 2011), i.e., its aid allocation is also motivated by Indian interests that are not directly related to the developmental concerns of its partner countries in the developing world. In this regard, the MEA (2004: 133) openly admits that " $[\mathrm{t}]$ he Government has been using development aid, including grants and Lines of Credit (LOCs) on concessional terms as tools for promotion of India's political, economic and commercial interests." With respect to commercial interests, Indian aid is seen as an instrument not only to gain access to overseas markets for its goods and services, but also to pave the way for Indian investment abroad (Price 2004; Agrawal 2007; Kragelund 2008). The fact that India's aid is mainly 'tied aid' suggests that commercial interests play a dominant role. Moreover, India's aid is said to be targeted at developing countries possessing oil and other natural resources in order to meet the rising demand for energy resources back home (e.g., Chanana 2009). While the MEA (2009: xiii) admits that its aid was "helping Indian companies get project contracts and orders for supply of goods," it is emphasized that "the LoCs have helped in infrastructure development in these regions thereby creating considerable goodwill for the country." With respect to the TEAM-9 $9^{13}$ program, Kragelund (2008) also identifies an overlap with the business activities of Indian oil companies.

In addition to commercial interests, the Indian foreign aid program is seen as a foreign policy tool to expand the country's geopolitical and diplomatic influence beyond the South Asian region, as well as an attempt to build military alliances elsewhere (e.g., Agrawal 2007). In this regard, Lafargue (2006) notes that Zambia, an Indian aid recipient, did not criticize India's nuclear tests in 1998 and recognized in 2003 that the Jammu and Kashmir regions are a part of India. Aid is considered a part of India's efforts to obtain support for the country's bid for a permanent seat in the United Nations Security Council (e.g., Kragelund 2008). ${ }^{14}$ Moreover, India perceives its aid program as a tool to improve its image around the world. In this regard, the MEA states that the ITEC program "has generated immense goodwill and substantive cooperation among the developing countries," and that it "constitutes an integral part of India's

\footnotetext{
${ }^{13}$ The Techno Economic Approach for Africa India Movement (TEAM-9) program offers LOCs to nine West African countries.

${ }^{14}$ Price (2004) hypothesizes that India, as an aid recipient, only accepts aid from three current permanent Council members and from three proposed Council members for the very same reason.
} 
South-South Cooperation effort which has been a traditional pillar of the country's foreign policy and diplomacy" (ITEC 2011). According to Agrawal (2007: 2), India aims to "develop a viable 'pro-India' constituency among key decision makers in recipient countries." Contrasting these views, Banerjee (1982: 54) argues that "India does not provide aid to its neighbours with the hope of extending its influence in the region." He criticizes allegations that India's aid was motivated by selfish motives. ${ }^{15}$ Focusing on how India can actually use aid as a foreign policy tool, Dutt (1980) lists five elements: first, to improve bilateral relations, second, to improve India's image, third, to gain leverage and influence over recipient countries, fourth, to reward recipients' policy position, and fifth, to maintain the stability and status quo in recipient countries. Taken together, we test the following hypothesis:

Hypothesis 2a: India's aid allocation is guided by India's political and commercial selfinterests.

With India emerging on the world stage as a significant provider of development assistance, critics of its aid program question the diversion of resources away from internal development given the chronic socio-economic problems plaguing India. It is this paradox which raises suspicion that India's aid has mainly been allocated in accordance with the country's own interests. We expect a "needy" donor to behave differently than a developed donor country. More precisely, the importance of self-interest should be larger in India's case than for "rich" donor countries for several reasons. First, a "needy" donor is more exposed to public criticism of its aid allocation because of domestic deficiencies. In order to defend its aid allocation vis-à-vis its electorate, the country might be more inclined to follow political and commercial interests to a larger extent. In this regard, Price (2004) notes that the Indian government had to emphasize the benefits that accrue to India in order to gain domestic support for its foreign aid policy, especially the aid reforms after the 2003-04 Finance Minister's budget speech. Note that this need to defend aid expenditure is even larger in democracies like India, where the government faces elections, than in autocratic donor countries. A second explanation is evident if one

\footnotetext{
15 Banerjee (1982) claims that India does not make recipient countries dependent on its assistance, instead strengthening their self-reliance. Moreover, he argues that India has not installed any military bases in a major recipient country.
} 
assumes a declining marginal utility of wealth, i.e., a "needy" donor like India values an additional dollar of wealth more than richer countries. The "needy" donor, lagging behind the "rich" donor in terms of wealth, consequently has more incentives to provide strategic aid than the "rich" donor does. We formulate the following hypothesis:

Hypothesis 2b: While the elasticity to recipient needs is lower for a "needy" donor like India compared to "rich" donors, the opposite is true for political and commercial factors in regards to their respective aid allocations.

\section{Empirical Analysis}

\subsection{Overview}

In this section, we employ data on aid commitments by the MEA in constant 2000 US dollars, obtained from the project-level database AidData (Findley et al. 2009). ${ }^{16}$ Data are available for the 2008-2010 period. In what follows, we only analyze aid projects traceable to countries, thus excluding aid provided to world regions if we lack information on the country breakdown. ${ }^{17}$ To follow the OECD's definition of ODA, we further exclude projects related to military assistance, as well as aid provided to countries that are not on the DAC list of aid recipients. ${ }^{18}$ Our aim is to estimate the motives behind India's aid allocation decisions. Beyond that, we compare India's aid allocation to that of other donor countries in order to investigate whether aid from the "needy" donor India is allocated based on different grounds.

The lion's share (89.7\%) of India's aid administered by the MEA was allocated to South Asian countries (see Figure 2). With the exception of Pakistan, all six South Asian countries were beneficiaries of Indian aid in this period of time. Southeast Asian countries received 5.5\% of MEA aid during this period. This corresponds to a total of 18 countries which have obtained development assistance in this region. $2.2 \%$ of the Ministry's total aid amount has been received by 38 Sub-Saharan African countries, and 1.6\% was directed to eight transition economies in

\footnotetext{
${ }^{16}$ While the first entry in the aid database is "Welfare Activities for the Muktijoddhas (Freedom Fighters)" in Bangladesh in 2008, the database ends with an IT center in Osh in the Kyrgyz Republic in 2010.

${ }^{17}$ About $5 \%$ of the total aid amount is not traceable to recipient countries.

${ }^{18}$ The DAC List of ODA Recipients is available at: http://www.oecd.org/dataoecd/23/34/37954893.pdf, as of January 1, 2006 (accessed February 14, 2011).
} 
Eastern Europe and Central Asia. In the Middle East and North Africa, only Palestine and Syria benefited from Indian aid (1.2\% of India's total aid amount in the 2008-2010 period). Indian support in this region was significantly concentrated on providing various types of humanitarian assistance to Palestine. Finally, less than $0.1 \%$ of total aid allocations by the MEA were made available to 10 Latin American countries. Taken together, it is evident that India strongly favors countries in its neighborhood, as has been argued previously (e.g., Price 2005; Katti et al. 2009; Meier and Murphy 2011).

Figure 3 puts the spotlight on sectoral aid allocations. As can be seen, 23.1\% of the aid committed was targeted to the energy sector (DAC code: 230), covering both the production and distribution of energy in recipient countries. The second most important sector was drinking water provision and sanitation facilities (DAC code: 140), making up 15.0\% of the Ministry's total aid amount. $12.8 \%$ of MEA aid was allocated to transport and storage facilities in recipient countries (DAC code: 210), closely followed by $11.8 \%$ earmarked for commodity aid and general program assistance (DAC code: 500), which includes contributions for general development purposes in recipient countries. We also find that about $9.5 \%$ of total aid was allocated towards the development of activities associated with strengthening the administrative apparatus and government planning, activities promoting good governance, strengthening civil society, and other social infrastructure projects in the recipient countries, respectively (DAC codes: 150 and 160). 8.7\% of the Ministry's aid was allocated to multi-sector activities (DAC code: 400 ), and $7.5 \%$ to the development of health-related activities such as building hospitals and health centers, and the provision of other health infrastructure (DAC code: 120). The MEA also earmarked 5.6\% for industrial development (DAC codes: 321-323). The remaining sectors are: education (3.2\%, DAC code: 110), communications (1.4\%, DAC code: 331-332), agriculture, forestry and fishing (0.5\%, DAC code: $311-313)$, humanitarian purposes $(0.9 \%$, DAC code: 700$)$ and unspecified $(0.5 \%$, DAC code: 998$)$. Finally, less than $0.1 \%$ is targeted at banking and financial services (DAC code: 240 ).

These numbers serve as a first indication that India's foreign aid is motivated more by commercial interests in comparison to need-based issues plaguing recipient countries. This is reflected in the fact that about $45 \%$ of the Ministry's aid has been directed at commercial sectors. Nevertheless, the development aid provided by the MEA also covers sectors concerned with the 
overall development of basic public goods (such as health, drinking water, education and agriculture), which made up about $24 \%$ of total aid allocations.

With respect to the role of developmental distance between India and recipient countries for aid allocation, Figure 4 provides first descriptive evidence in favor of hypothesis $1 \mathrm{~b}$. The graph on the left shows the expected negative link between the (logged absolute) developmental distance and the probability of receiving aid from India. The graph on the right, however, shows only a weak negative correlation between developmental distance and (logged) aid commitments from India. We now turn to the econometric analysis.

\subsection{Data and Methodology}

We follow a common practice in the aid allocation literature and estimate India's aid allocation in two steps (e.g., Neumayer 2002). First, we estimate which countries enter India's aid program. Our dependent variable is a dummy that takes a value of 1 if India provided aid to a developing country on the DAC list of aid recipients. Second, given that a country receives aid from India, we estimate the (logged) amount of aid in US dollars that has been committed to a particular recipient country. One way to estimate the first step (the so-called gate-keeping stage) is through a Probit (or Logit) model, which takes the binary nature of the data into account. In the second step, it may be preferable to include the inverse Mills ratio derived from the first step to avoid selection bias. Since we lack a suitable exclusion variable, we run a Heckman model without an exclusion variable, i.e., we identify the model based on the non-linearity inherent in the selection equation. The resulting Wald test does not reject the null hypothesis of independent equations (pvalue: 0.650). ${ }^{19}$ Therefore, we opt for an Ordinary Least Squares (OLS) estimation of the aid amount allocated to a recipient country.

For our econometric analysis, we sum bilateral aid allocation over the 2008-2010 period since it is difficult to explain aid allocation on a yearly basis due to its volatility (see also Gupta et al. 2006; Dreher et al. 2011). Concerning the selection of our explanatory variables, we follow the previous literature on aid allocation, in particular that on emerging donors (e.g., Dreher et al. 2011; Dreher and Fuchs 2011). To control for the effect of geographic proximity, we account for

\footnotetext{
${ }^{19}$ Results available upon request.
} 
the (logged) distance between the recipient and donor country. ${ }^{20}$ Distance can be seen as a proxy for costs associated with the provision of development aid. Aid costs are expected to be a particular concern for a "needy" donor with limited resources like India. Apart from this explanation, India might favor countries in its neighborhood (with the exception of Pakistan due to the bilateral conflict over Kashmir) as it aspires to become a regional power. Dreher et al. (2011) find that, in general, so-called new donors are more likely to provide aid to countries that are closer to them geographically. Given that India is even poorer in terms of income per capita than any of the donors covered in Dreher et al. (2011), we expect to find a pronounced effect of distance on aid allocation for the "needy" donor under investigation.

We use several variables to examine whether India's aid responds to the needs of other developing countries (hypothesis 1a). To reflect humanitarian motives, the need orientation of donors is proxied by the recipient country's (logged) GDP per capita (measured in 2005 international dollars). A need-oriented donor should provide more aid to poorer countries. Thus, we expect a negative sign for this income measure. Next, we control for the (log) population of recipient countries. The intuition here is that larger countries need more resources to obtain visible effects of aid provision. In addition, we control for the (log) total number of people affected by natural disasters as an additional indicator of recipient need since disaster relief is part of the aid program of the MEA. Furthermore, we include developmental distance, which is measured as the (log) absolute difference between the income per capita of India and that of a particular recipient country. Hypothesis $1 \mathrm{~b}$ implies that India's aid decreases with the developmental distance to a recipient country.

To proxy donors' political self-interests, we follow the literature and employ a recipient country's voting alignment with India in the United Nations General Assembly (UNGA). The UNGA voting alignment seems to be of large relevance for India since "marshalling support for Indian positions in forums such as the UN take up much of India's diplomatic effort" (Dutt 1980: 678). Relying on data from Voeten and Merdzanovic (2009), we calculate the number of times a country votes in line with India (either both voting yes, both voting no, both voting abstentions, or both being absent). We then divide the resulting value by the total number of votes in a

\footnotetext{
${ }^{20}$ As defined in Mayer and Zignago (2006), bilateral distances are computed as the average of the distance between the major cities of the two countries, which are weighted by the share of the city in the overall population.
} 
particular year to derive a measure of voting coincidence between zero and one. We follow Dreher et al. (2011) and compute the voting alignment based on key votes as defined by the U.S. State Department (Kilby 2009b). ${ }^{21}$ Various empirical studies find that developing countries are favored in donors' aid allocation decisions when they have closer political ties (Thacker 1999; Alesina and Dollar 2000; Barro and Lee 2005; Dreher et al. 2009; Kilby 2009a). We also include a dummy variable that takes a value of 1 if a recipient country is a non-suspended member of the Commonwealth of Nations. It can be argued that India uses the Commonwealth as a forum to develop political and commercial ties. For example, over the years India has developed strong ties with Commonwealth countries in South and Southeast Asia, as well as Africa (Johnson and Kumar 2011). Beyond that, referring to colonization, Banerjee (1982: 54) views India's aid "as a part of the process to undo the injustice of ages."

To account for commercial interests, we include India's (log) total exports to a particular recipient country in constant US\$. In addition, we follow Dreher et al. (2011) and use the recipient country's (log) depletion of mineral and energy resources as a proxy for a recipient's endowment of natural resources.

Finally, to account for merit as a motive for aid supply, institutional quality in the recipient countries is proxied by both the political rights measure from Freedom House (2009) and the corruption index from Kaufmann et al. (2009). The political rights variable is coded on a scale of 1-7, with higher values representing worse liberties, and lower values reflecting full liberties. As the world's largest democracy, India might reward democratic countries and provide less aid to autocratic countries in comparison. Note that India is the second largest donor in the UN Democracy Fund (US\$ 25 million as of 5 January 2012), which underlines the importance that India attributes to the support of democratization. ${ }^{22}$ Alternatively, India might follow the 'spirit of Bandung' (Lafargue 2006) and follow the principle of non-interference in internal affairs, i.e., its aid allocation might be independent of the institutional characteristics of the recipient country. If this is the case, we would expect India to be unresponsive to corruption in

\footnotetext{
${ }^{21}$ Note that we also report the results with all votes as a robustness check.

22 See UNDEF webpage: http://www.un.org/democracyfund/Donors/donors_index.html (accessed 11 February 2012).
} 
the recipient countries. The control-of-corruption index ranges from -2.5 to 2.5 , with higher values corresponding to better governance.

For our time-varying explanatory variables, we take lagged values, i.e., the corresponding value in 2007 , to mitigate endogeneity issues. The only exception is the disaster variable since it is reasonable to assume that the occurrence of natural catastrophes is exogenous. Since our export variable and UNGA voting alignment both show relatively high volatility over time, we follow Dreher et al. (2011) and take the average of the respective values in the three years preceding our period of investigation (2005-2007). All definitions and sources of variables are provided in Appendix A1.

\subsection{Main Results}

Table 1 displays our results. While columns 1-3 show the results for the gate-keeping stage, columns 4-6 highlight the results of the allocation decision. Analyzing the coefficient on GDP per capita in column 1, Indian aid shows some need orientation. The probability that a developing country receives aid from India decreases with a country's stage of development. The coefficient is statistically significant, at the ten-percent level. In turn, both the number of people affected by natural disasters and country size have no significant impact on the probability that a developing country enters India's aid program, at conventional levels of significance. ${ }^{23}$ To test whether India favors countries at a similar developmental stage (hypothesis 1b), we add the developmental distance to India to our regression in column 2. The corresponding coefficient shows the expected negative sign and is statistically significant, at the ten-percent level. Note that the coefficient on per-capita GDP loses its statistical significance. Considering that the developmental distance between India and developing countries is correlated with the recipient's income per capita, we drop this latter variable as a next step. As shown in column 3, we find that developmental distance becomes statistically significant, even at the five-percent level. This suggests that countries closer to India in terms of economic development are favored by the MEA, in line with hypothesis $1 b$.

\footnotetext{
${ }^{23}$ Note that the coefficient on disasters becomes statistically significant in column 2 , at the ten-percent level. The significant negative sign is evidence against the hypothesis that disaster-stricken countries are more likely to enter India's aid program.
} 
According to all three specifications (columns 1-3), countries which are closer to India geographically are favored. The probability that a country receives aid from India decreases with distance, at the one-percent level of significance. The political and commercial variables do not have a significant effect on Indian aid in the gate-keeping stage. The coefficient on the UNGA voting alignment on key votes, the Commonwealth dummy, and the variable capturing the extraction of natural resources are all not statistically significant at conventional levels. Note that the Indian exports variable gains statistical significance in column 3, at the five-percent level, but the suggested negative effect is not robust (see columns 1 and 2). The indicators of recipient merit, political rights and control of corruption are not statistically significant at conventional levels in all three specifications. This finding would support the idea that India's aid allocation today still follows the 'spirit of Bandung', with the principle of non-interference in internal affairs.

Analyzing the allocation decision (column 4), we do not find a significant link between a recipient country's stage of development and the amount of aid received. This also holds true if we use the developmental distance between India and the recipient instead of the recipient country's GDP per capita (column 6), or if we include both variables at the same time (column 5). While this finding questions India's commitment towards recipient need at the allocation stage, we obtain a nuanced picture if we consider the effect of the number of people affected by disasters. While we did not find that disaster-affected countries are more likely to enter India's aid program, countries suffering from more severe natural disasters receive larger aid amounts if they are already among India's aid recipients. If the number of people affected increases by one percent, India's aid commitments increase by about 0.1 percent. Our results also show that larger countries are disfavored as the coefficient on population is negative and statistically significant, at the one-percent level. While this result seems surprising at first, it is in line with empirical evidence for China (Dreher and Fuchs 2011) and six other so-called new donors (Dreher et al. 2011). As was the case in the gate-keeping stage, geographic proximity is also an important determinant of aid amounts. A one-percent increase in the distance from India to a particular recipient country decreases India's aid commitments by about 1.6 percent, on average.

Political and commercial motives are also important for India's aid allocation decisions. Recipients with both a closer voting alignment with India in the UNGA on key votes and 
stronger commercial ties (proxied by Indian exports to recipient countries) do in fact receive larger aid flows from the "needy" donor, with both coefficients being significant, at the onepercent level. If the voting alignment increases by ten percentage points, India increases its aid commitments by roughly $0.7 \%$, on average. Accordingly, if Indian exports grow by one percent, aid increases by $0.4 \%$. These results support hypothesis $2 \mathrm{a}$. In contrast to our expectations, however, India disfavors countries that are members of the Commonwealth. The coefficient on the Commonwealth dummy shows a surprising negative sign and is statistically significant, at the one-percent level. It seems that India uses its aid to strengthen ties with those developing countries with which it does not already cooperate with through the Commonwealth of Nations. Moreover, recipient countries' extraction of natural resources does not have the expected positive impact on the size of India's aid flows. While we do not find a statistically significant effect of political rights on aid amounts provided by India, aid flows are significantly larger to countries with a relatively low level of corruption, at the one-percent level of significance, and in contrast to our findings at the gate-keeping stage.

Overall, the empirical results lend some support in favor of our "needy" donor hypotheses. First, countries at a similar developmental stage are more likely to enter India's aid program (but do not receive larger aid amounts). Second, political and commercial interests have an impact on the size of India's aid flows. As a next step, we will compare the role that political and commercial motives play in India's aid allocation decisions with aid flows from richer donors. By doing this, we test whether aid allocation from the "needy" donor India is driven to a higher extent by political and commercial motives than is the case for richer donor countries (hypothesis 2b).

\subsection{Comparison with DAC and Other Non-DAC Donors}

Finally, we compare India's aid allocation with other donors to evaluate whether aid from the "needy" donor under investigation is special. ${ }^{24}$ Dutt (1980, p. 676) expects India's aid allocation to be closer to that of the big powers than to Scandinavian aid since "Indian elites perceive India as having a role on the world stage," an assessment that became even more evident after the 2003 budget speech. The pattern of India's aid allocation is compared to the following longstanding

\footnotetext{
${ }^{24}$ Data on aid allocation from the countries under comparison were obtained from the OECD (2012).
} 
members of the DAC: the United States, Japan, the three largest EU countries (Germany, France and the United Kingdom) and the so-called 'like-minded donors' or 'good donors' (Canada, Denmark, Netherlands, Norway and Sweden). This latter group is said to provide development aid predominantly based on humanitarian motives. ${ }^{25}$ Beyond that, we compare India's aid allocation with that of South Korea, another large emerging Asian donor, which became a DAC member in 2009, and with the United Arab Emirates, which has provided sizable aid amounts since the oil crises of the 1970s. Data on ODA from these donors again cover the 2008-2010 period, and are obtained from the OECD (2012). Unfortunately, we cannot compare India with China, the largest non-DAC donor, since we lack sufficient data on China's foreign aid after 2005 (see Dreher and Fuchs 2011 for a discussion). We use a similar set of explanatory variables as in our baseline model in column 1 of Table 1 . Note that we replace the Commonwealth dummy, which is an India-specific variable, with a general dummy variable for common colonial history between the donor and recipient. More precisely, the variable takes a value of one if donor and recipient had a common colonizer (e.g., the British Crown in the case of India) or if the recipient was a colony of the donor country after 1945 as defined in Mayer and Zignago (2006). Moreover, we now employ the recipient's UNGA voting alignment on key votes with the respective donor (not necessarily India) and, analogously, we take the exports of the respective donor to a recipient economy.

In order to be able to compare the effects between donors, we run nested regressions rather than individual regressions for each donor (see also Berthélemy 2006; Dreher et al. 2011; Dreher and Fuchs 2011). This is done by interacting dummies for each donor country or donor group with each of our explanatory variables. In addition to the coefficients and the corresponding p-value of all explanatory variables for all donors (in parentheses), we compute the p-values of a Wald test for differences in the effect of a variable for a particular country and India (in italics).

Table 2 displays our results. Analyzing the role of recipient needs as measured by GDP per capita, we find that Indian aid shows the smallest need orientation than of all donors under

\footnotetext{
${ }^{25}$ Note that doubts have been raised as to whether the positive image of these donor countries is warranted (see, for example, Neumayer (2003b) with respect to human rights, or Strømmen et al. (2011) with respect to peace and human security). Similarly, in their ranking of aid agency practices, Easterly and Williamson (forthcoming) find that Scandinavian donors perform surprisingly badly.
} 
investigation. The coefficient on GDP per capita for India is the smallest in absolute terms and significantly different from the EU-3 and the "good" donors, at least at the five-percent level of significance (see p-values of the Wald test in italics). Moreover, India is the only donor for which population size has a negative effect on aid commitments that is statistically significant at conventional levels, which questions India's actual concern for recipient needs. Only with respect to disaster response does India show some need orientation. Apart from Japan, India is the only donor with a statistically significant and positive coefficient on the number of people affected by disasters.

The effect of geographic distance between the donor and recipient is the largest for India compared to all other donors included in the analysis. This can be interpreted as evidence that aid costs matter more for a "needy" donor than for "rich" donors. The p-values of the Wald test in italics show that the distance coefficient for India is significantly different, at least at the five percent level, from the U.S., the EU-3 and the "good" donors. Analyzing the impact of the UNGA voting alignment on aid allocation, the coefficient for India is found to be the largest among the donors under investigation. While Indian aid is significantly more motivated by politics than aid from all traditional DAC donors, the difference between the coefficients is not statistically significant with respect to South Korea and the United Arab Emirates. While countries that share a common colonial legacy do not receive higher aid amounts from India and are even receiving less aid on average, the EU-3 and the "good" donors provide significantly more aid to countries which have had a colonial relationship with the respective donor country.

The effect of bilateral exports on aid amounts is larger for India than for any of the other donors under investigation. According to the p-values of the Wald test in italics, Indian aid has a significantly closer link to commercial relationships than aid from the "good" donors. With regard to its relationship with natural resource endowments, we find that neither of the donors rewards countries possessing natural resources through increased aid flows. Likewise, we do not find evidence that any of the donors under investigation reward countries with greater political rights. Finally, we find that, alongside India, Japan is the only other donor that provides significantly larger amounts of aid to recipients that score better on the control-of-corruption index, at conventional levels of significance. Taken together, while commercial interests do not seem to play a significantly larger role for India than for "rich" donors according to this 
robustness check, the sub-sample analysis largely confirms the outstanding importance of political interests compared to most traditional DAC donors.

\subsection{Robustness checks}

Next, we examine the robustness of our findings. To begin with, we analyze nine additional variables that might influence India's aid commitments in addition to those included in columns 1 and 4, respectively. First, Indian aid allocation decisions are said to be related to the prevalence of Indian diaspora communities (e.g., Dutt 1980; Banerjee 1982; Lafargue 2006). ${ }^{26}$ The (log) Indian migrant stock in recipient countries is obtained from two sources, namely the Global Migrant Origin Database (Parsons et al. 2007) and the MEA (2001). Second, in order to examine whether India targets traditional recipients of aid from China, we include a variable capturing the number of completed Chinese aid projects in recipient countries as a share of China's total aid over the 1996-2005 period (see definition in Dreher and Fuchs 2011). A positive sign could suggest aid competition between the two emerging Asian powers, as suggested by some scholars (see Cheru and Obi 2011, for instance). Third, we replace a recipient country's GDP per capita with its (logged) infant mortality rate (children under the age of 5) as an alternative measure of India's need orientation. Fourth, we add a dummy for countries which share a border with India to test whether India favors its direct neighbors in addition to the role played by geographic distance. Fifth, we replace the UNGA voting alignment index covering key votes with an index that covers all votes. Sixth, to allow for an alternative definition of what constitutes a key vote from the Indian perspective, we consider only those votes which show opposite voting behavior to the United States on the one hand, and to the four BRIC countries on the other. More precisely, we construct a voting alignment index based on those votes where Brazil, Russia, India and China vote 'yes' and the United States votes 'no' (or vice versa). This measure should reflect the one-dimensional voting pattern that continues to exist in the General Assembly after the end of the Cold War, with the United States and its Western allies on one pole and a "counterhegemonic voting bloc," most notably the rising powers, on the other (see Voeten 2000). Seventh, we replace the Commonwealth dummy with a dummy that takes a value of 1 if India

\footnotetext{
${ }^{26}$ Lafargue (2006) identifies Indian diaspora as intermediaries for Indian investments in their respective host country.
} 
and a recipient country share a common language (i.e., English). Eighth, the Commonwealth dummy is substituted by a dummy variable that takes a value of 1 if the recipient country and India had a common colonizer after 1945 (i.e., the British Crown). Ninth, we replace the political rights measure with a dummy capturing whether a recipient country qualifies as a democracy as defined in Cheibub et al. (2010).

Detailed tables containing the regression results are reported in Appendices B1 and B2. In the gate-keeping stage (see Appendix B1), we do not find any statistical significance for the variables listed above, at conventional levels of significance. Furthermore, neither Indian diaspora communities nor aid projects lead to a significant increase (or decrease) in the probability that a developing country enters India's aid program. The outlined changes in the definition of the various explanatory variables do not change our main conclusions. In the allocation stage, we confirm the large positive significant effect of a country's UNGA voting alignment when we use the two alternative definitions instead. Note that the common colony dummy takes a negative sign, at the one-percent level, in line with our results for the Commonwealth dummy. Apart from these variables, all other variables introduced do not reach statistical significance at conventional levels.

Finally, we run a sub-sample analysis by restricting our sample to those countries that receive aid from India. Aware that this approach has its limitations, we intend to control for differences between the sample of India's aid recipients and that of other donors. ${ }^{27}$ As before, we run nested regressions by interacting dummies for each donor country with each of our explanatory variables. By construction, the results for India are exactly the same as those reported in Table 2. With respect to per-capita GDP, the respective coefficients for the United States, Japan and South Korea lose their statistical significance. When restricting the sample to Indian aid recipients only, Indian aid does not appear to be inferior with respect to need orientation compared to all other donors under investigation (see p-values of the Wald test in italics). Concerning the UNGA voting alignment, however, our results confirm the high importance of political interests in India's aid allocation. The respective coefficient for India is still larger than for any traditional DAC donor, the difference being statistically significant, at least at the five-percent level (except for the United States). Note that the coefficient on UNGA

\footnotetext{
${ }^{27}$ Our sample includes 51 countries that receive aid from India in the 2008-2010 period.
} 
voting alignment is now larger for South Korea than for India, but the difference is not statistically significant at conventional levels (as indicated by the p-value in italics). Although the EU-3, South Korea and UAE retain the expected sign and level of significance on bilateral exports, "good" donors and Japan are now positive and significantly different from zero, at the one-percent level. Finally, we also find some changes with respect to the corruption variable. We now find that the coefficients for the EU-3 and the "good" donors (along with India and Japan) become positive and statistically significant, at least at the five-percent level of significance. With respect to population size, mineral and energy depletion, and political rights, our results largely mimic those in Table 2 .

\section{Conclusions}

Despite having a large amount of its population suffering from underdevelopment, chronic poverty and mal-governance, India has jumped on the bandwagon in the 'business' of development aid. This is puzzling. According to a recent World Bank report on India, about 37\% of the Indian population lives on less than US\$ 1.25 a day (World Bank 2011). Although India has a large number of anti-poverty schemes and programs to tackle these problems, the progress made in poverty reduction is rather small. Against this background, it is ironic that India provides development aid to other developing countries. Many of India's aid recipients even have a larger income per capita than India. ${ }^{28}$ In fact, India's ongoing commitment to provide external assistance to aid-seeking countries is reflected in the government's decision to set up a separate agency by 2012, which will oversee the emerging donor's aid allocation process.

With the intension of learning why poor countries such as India provide foreign aid, this paper has made an attempt to empirically analyze India's aid allocation decisions. We utilized data on aid commitments by the Ministry of External Affairs to 127 developing countries in US dollars, obtained from the AidData database for the 2008-2010 period. To examine whether India is different, we also compared India's aid allocation decisions with those of other donors. Our

\footnotetext{
2823 recipients of Indian aid had a income per capita than India (based on 2007 values of GDP per capita in international dollars and purchasing power parity): Armenia, Belarus, Bhutan, Botswana, Cape Verde, Cuba, Ecuador, El Salvador, Fiji, Grenada, Indonesia, Jamaica, Maldives, Marshall Islands, Mauritius, Namibia, Samoa, Sao Tome and Principe, Seychelles, Sri Lanka, Tonga and Turkmenistan.
} 
empirical results show that India's aid allocation is partially in line with our expectations of the behavior of a "needy" donor. Commercial and political self-interests dominate India's aid allocation. We find the importance of political interests, proxied by UNGA voting alignment, to be significantly larger for India than for all DAC donors under investigation. Moreover, India favors countries which are geographically closer, and countries at a similar developmental stage are more likely to enter India's aid program.

From our results, it appears that the "needy" donor India predominantly cares about its own needs rather than the needs of others. Given India's domestic problems, this is understandable. Although India's own interests dominate its aid allocation, it may nevertheless be the case that India's assistance is effective in terms of poverty reduction and other developmental goals with respect to recipient countries. ${ }^{29}$ This merits further investigation. Concerning political self-interest, Agrawal (2007) raises doubts over the long-term political gains resulting from India's engagement. Future research may also evaluate whether Indian aid, officially aimed at the promotion of India's welfare in addition to that of aid recipients, actually supports India's own development.

While we find that India's allocation is partially in line with our expectations of a "needy" donor, India itself does not want to be perceived as such. This is made clear by the comments of India's Minister of Finance, Pranab Mukherjee, who characterized British aid to India as a "peanut" compared to India's own development expenditures. ${ }^{30}$ Moreover, India made its ambitions clear by announcing to setup a foreign aid agency, which is said to manage the distribution of aid flows amounting to 11 billion US dollars over the next five to seven years. ${ }^{31}$ If India aspires to be recognized as one of the big aid donors, it would be beneficial from India's point of view to, first, establish clearly outlined aid legislation, and second, increase its aid transparency. Clearly identified goals and the provision of detailed and transparent aid records

\footnotetext{
${ }^{29}$ If this is the case, India's aid would differ from DAC aid. Analyzing the effect of aid on growth, empirical evidence in Kilby and Dreher (2010) suggests that donor motives matter for aid effectiveness.

30 "India tells Britain: We don't want your aid," The Telegraph, 4 February 2012, available at: http://www.telegraph.co.uk/news/worldnews/asia/india/9061844/India-tells-Britain-We-dont-want-your-aid.html (last accessed: May 28, 2012).

31 "Aid 2.0," The Economist, 13 August 2011, available at: http://www.economist.com/node/21525899 (last accessed: May 28, 2012).
} 
will not only alleviate India's credibility as an emerging aid donor, but will also enhance the scope for coordination with other aid donors. 


\section{References}

Agrawal, Subhash, 2007, Emerging Donors in International Development Assistance: The India Case, International Development Research Centre, Partnership and Business Development Division.

Alesina, Alberto and David Dollar, 2000, Who Gives Foreign Aid to Whom and Why? Journal of Economic Growth 5, 1: 33-63.

Banerjee, Brojendra Nath, 1982, India's Aid to Its Neighbouring Countries, New Delhi: Select Books.

Banerjee, Kaustav, 2010, Social Development Index, Social Development Report 2010, New Delhi: Oxford University Press.

Barro, Robert J. and Jong-Wha Lee, 2005, IMF Programs: Who Is Chosen and What Are the Effects? Journal of Monetary Economics 52, 7: 1245-1269.

Basu, Kaushik, 2008, The Enigma of India's Arrival: A Review of Arvind Virmani's Propelling India: From Socialist Stagnation to Global Power, Journal of Economic Literature 46, 2: 396-406.

Basu, Kaushik and Annemie Maertens, 2007, The Pattern and Causes of Economic Growth in India, Oxford Review of Economic Policy 23, 2: 143-67.

Berthélemy, Jean-Claude, 2006, Bilateral Donors' Interests vs. Recipients' Development Motives in Aid Allocation: Do All Donors Behave the Same? Review of Development Economics 10, 2: 179-194.

Chanana, Dweepa, 2009, India as an Emerging Donor, Economic and Political Weekly XLIV, 12: 11-14.

Chaturvedi, Sachin, 2008, Emerging Patterns in Architecture for Management of Economic Assistance and Development Cooperation: Implications and Challenges for India, RIS Discussion Paper 139, Research and Information System for Developing Countries, New Dehli, India.

Cheibub, José A., Jennifer Gandhi and James R. Vreeland, 2010, Democracy and Dictatorship Revisited, Public Choice 143, 1-2: 67-101. 
Cheru, Fantu and Cyril Obi, 2011, Genuine Partnership or a Marriage of Convenience? Foreign Policy in Focus (FPIF), accessed from: http://www.fpif.org/articles/genuine_partnership_or_a_marriage_of_convenience.

Dreher, Axel and Andreas Fuchs, 2011, Rogue Aid? The Determinants of China's Aid Allocation, Courant Research Centre 'Poverty, Equity and Growth' Discussion Paper 93. University of Goettingen, Germany.

Dreher, Axel, Peter Nunnenkamp and Rainer Thiele, 2011, Are 'New' Donors Different? Comparing the Allocation of Bilateral Aid between Non-DAC and DAC Donor Countries, World Development 39, 11: 1950-68.

Dreher, Axel, Jan-Egbert Sturm and James Vreeland, 2009, Development Aid and International Politics: Does membership on the UN Security Council influence World Bank decisions? Journal of Development Economics 88, 1: 1-18.

Dreze, Jean and Amartya Sen, 2011, Putting Growth in Its Place, Outlook, November 14, available at: http://www.outlookindia.com/article.aspx?278843 (accessed June 2012).

Dutt, Srikant, 1980, Indian Aid to Co-Developing Countries, Economic and Political Weekly, $15(5), 672-78$.

Easterly, William and Claudia Williamson, Rhetoric versus Reality: The Best and Worst of Aid Agency Practices, World Development, forthcoming.

ECOSOC, 2008, Trends in South-South and Triangular Development Cooperation, Background Study for the Development Cooperation Forum, United Nations Economic and Social Council.

EM-DAT, 2010, The OFDA/CRED International Disaster Database, Université Catholique de Louvain, Brussels, Belgium, available at: http://www.emdat.be (accessed October 2010).

Findley, Michael G., Darren Hawkins, Robert L. Hicks, Daniel L. Nielson, Bradley C. Parks, Ryan M. Powers, J. Timmons Roberts, Michael J. Tierney and Sven Wilson, 2009, AidData: Tracking Development Finance, presented at the PLAID Data Vetting Workshop, Washington, DC.

Freedom House, 2009, Freedom in the World 2009, available at: http://www.freedomhouse.org (accessed: 13 February 2010). 
Global Hunger Index 2011, Accessed from: http://www.ifpri.org/publication/2011-globalhunger-index.

Gupta, Sanjeev, Catherine Pattillo and SmitaWagh, 2006, Are Donor Countries Giving More or Less Aid? Review of Development Economics 10, 3: 535-552.

ITEC, 2011, Official Website of Technical Cooperation Division, Ministry of External Affairs, Government of India, available at: http://itec.mea.gov.in/ (accessed: 11 October 2011).

Johnson, Jo and Rajiv Kumar, 2011, Reconnecting Britain and India: Ideas for an Enhanced Partnership, New Dehli: Academic Foundation.

Katti, Vijaya, Tatjana Chahoud, and Atul Kaushik (2009) India's Development Cooperation Opportunities and Challenges for International Development Cooperation, Briefing Paper no. 3, German Development Institute (DIE): Bonn.

Kaufmann, Daniel, Aart Kraay and Massimo Mastruzzi, 2009, Governance Matters VIII. Governance Indicators for 1996-2008, available at: http://info.worldbank.org/governance/wgi/pdf/ wgicharts.xls (accessed: 13 February 2010).

Kilby, Christopher, 2006, Donor Influence in Multilateral Development Banks: The Case of the Asian Development Bank, Review of International Organizations 1, 2: 173-195.

Kilby, Christopher, 2009a, The Political Economy of Conditionality: An Empirical Analysis of World Bank Loan Disbursements, Journal of Development Economics 89, 1: 51-61.

Kilby, Christopher, 2009b, Donor Influence in International Financial Institutions: Deciphering What Alignment Measures Measure. Paper presented at the Political Economy of International Organizations Meeting, Geneva, Switzerland.

Kilby, Christopher and Axel Dreher, 2010, The Impact of Aid on Growth Revisited: Do Donor and Recipient Characteristics Make a Difference? Economics Letters 107, 3: 338-340.

Kragelund, Peter, 2008, The Return of Non-DAC Donors to Africa: New Prospects for African Development? Development Policy Review 26, 5: 555-84.

Kragelund, Peter, 2010, The Potential Role of Non-Traditional Donors' Aid in Africa, ICTSD Issue Paper No. 11, Geneva: International Centre for Trade and Sustainable Development. 
Kuziemko, Ilyana and Eric Werker, 2006, How Much is a Seat on the Security Council Worth? Foreign Aid and Bribery at the United Nations, Journal of Political Economy 114, 5: 905-30.

Lafargue, François, 2006, L'Inde en Afrique: Logiques et limites d'une Politique, Afrique contemporaine $219,137-48$.

Manning, Richard, 2006, Will Emerging Donors Change the Face of International Co-operation? Development Policy Review 24, 4: 371-85.

Meier, Claudia and C. S. R. Murphy, 2011, India's Growing Involvement in Humanitarian Assistance, GPPi Research Paper No. 13, Berlin: Global Public Policy Institute.

Mayer, Thierry and Soledad Zignago, 2006, Notes on CEPII's Distances Measures, available at: http://www.cepii.fr/anglaisgraph/bdd/distances.htm (accessed: May 2009).

MEA, 1997-2006, Annual Report, Ministry of External Affairs, Government of India, available at: http://www.meaindia.nic.in and http://mealib.nic.in/ (accessed: 25 October 2010).

MEA, 2001b, Estimated Size of Overseas Indian Community: Country-wise, Non Resident Indians \& Persons of Indian Origin Division, Ministry of External Affairs, Government of India, available at: http://indiandiaspora.nic.in/diasporapdf/part1-est.pdf (accessed: 14 February 2011).

MEA, 2011, Earthquake and Tsunami in Japan - a Situation Update, available at: http://mea.gov.in/mystart.php?id=190017406

Neumayer, Eric, 2002, Is Good Governance Rewarded? A Cross-National Analysis of Debt Forgiveness. World Development 30, 6: 913-930.

Neumayer, Eric, 2003a, What Factors Determine the Allocation of Aid by Arab Countries and Multilateral Agencies? Journal of Development Studies 39, 4: 134-47.

Neumayer, Eric, 2003b, Do Human Rights Matter in Bilateral Aid Allocation? A Quantitative Analysis of 21 Donor Countries, Social Science Quarterly 84, 3: 650-666.

Neumayer, Eric, 2004, Arab-related Bilateral and Multilateral Sources of Development Finance: Issues, Trends, and the Way Forward, World Economy 27, 2: 281-300.

Neumayer, Eric, 2005, Is the Allocation of Food Aid Free from Donor Interest Bias? Journal of Development Studies 41, 3: 394-411. 
OECD, 2012, Creditor Reporting System Aid Activities Database, available at: http://stats.oecd.org/Index.aspx (last accessed: 21 March 2012).

Panagariya, Arvind, 2010, India: The Emerging Giant, Oxford University Press: USA.

Parsons, Christopher R., Ronald Skeldon, Terrie L. Walmsley, and L. Alan Winters, 2007, Quantifying international migration: a database of bilateral migrant stocks, Policy Research Working Paper Series 4165, The World Bank.

Patel, Nishika, 2011, India to Create Central Foreign Aid Agency, Global Development, available at: http://www.guardian.co.uk/global-development/2011/jul/26/india-foreignaid-agency.

Price, Gareth 2005, Diversity in Donorship: The Changing Landscape of Official Humanitarian Aid - India's Official Aid Programme, London: ODI.

Price, Gareth, 2004, India's Aid Dynamics: From Recipient to Donor? Asia Program Working Paper, London: Chatham House.

Sinha, Pranay and Michael Hubbard, 2011, DAC (Traditional) \& Non DAC (Emerging) Donors at the Crossroads: The Problem of Export Credits, Paper presented at the EADI-DSA 2011 Conference, University of York, available at: http:/www.birmingham.ac.uk/Documents/college-social-sciences/governmentsociety/idd/research/aid-data/problem-export-credits.pdf.

Strømmen, Marthe A., Indra de Soysa and Krishna Chaitanya Vadlamannati, 2011, How Kind the Good Samaritan? An Empirical Test of Scandinavian Aid and the Promotion of Peace and Human Rights, 1960-2009, ISS working paper, Norwegian University of Science and Technology, Trondheim.

Thacker, Strom C., 1999, The High Politics of IMF Lending, World Politics 52: 38-75.

UNCTAD, 2010, World Investment Report 2010, available at: http://www.unctad.org (accessed: 26 January 2011).

UNESCO, 2011, UNESCO Institute for Statistics, Education Statistics, available at: http://stats.uis.unesco.org/ (accessed: 20 December 2011).

Voeten, Erik, 2000, Clashes in the Assembly, International Organization 54, 2: 185-215.

Voeten, Erik and Adis Merdzanovic, 2009, United Nations General Assembly Voting Data, available at: http://hdl.handle.net/1902.1/12379 (accessed: June 2010). 
World Bank, 2011, Social Protection for Changing India: Volume 1, Washington DC: The World Bank, available at: http://go.worldbank.org/OMQD3XEWJ0 (accessed: 10 June 2011). 
Table 1: Allocation of India's aid commitments (2008-2010)

\begin{tabular}{|c|c|c|c|c|c|c|}
\hline & \multicolumn{3}{|c|}{$\begin{array}{l}\text { SELECTION } \\
\text { Probit }\end{array}$} & \multicolumn{3}{|c|}{$\begin{array}{c}\text { ALLOCATION } \\
\text { OLS }\end{array}$} \\
\hline & $(1)$ & (2) & (3) & (4) & (5) & (6) \\
\hline (log) GDP per capita & $\begin{array}{c}-0.315^{*} \\
(0.060)\end{array}$ & $\begin{array}{r}-0.244 \\
(0.182)\end{array}$ & & $\begin{array}{l}-0.241 \\
(0.226)\end{array}$ & $\begin{array}{l}-0.243 \\
(0.209)\end{array}$ & \\
\hline (log) Developmental distance & & $\begin{array}{c}-0.228^{*} \\
(0.097)\end{array}$ & $\begin{array}{l}-0.268^{* *} \\
(0.039)\end{array}$ & & $\begin{array}{c}0.012 \\
(0.936)\end{array}$ & $\begin{array}{l}-0.015 \\
(0.924)\end{array}$ \\
\hline (log) Affected from disasters & $\begin{array}{r}-0.060 \\
(0.137)\end{array}$ & $\begin{array}{c}-0.079 * \\
(0.059)\end{array}$ & $\begin{array}{l}-0.063 \\
(0.126)\end{array}$ & $\begin{array}{c}0.111^{* *} \\
(0.037)\end{array}$ & $\begin{array}{c}0.112^{*} \\
(0.055)\end{array}$ & $\begin{array}{c}0.126^{* *} \\
(0.015)\end{array}$ \\
\hline (log) Population & $\begin{array}{r}0.028 \\
(0.852)\end{array}$ & $\begin{array}{c}0.060 \\
(0.697)\end{array}$ & $\begin{array}{c}0.113 \\
(0.438)\end{array}$ & $\begin{array}{l}-0.526^{* * *} \\
(0.002)\end{array}$ & $\begin{array}{l}-0.530 * * * \\
(0.004)\end{array}$ & $\begin{array}{l}-0.451^{* *} \\
(0.012)\end{array}$ \\
\hline (log) Distance & $\begin{array}{l}-0.847^{* * *} \\
(0.001)\end{array}$ & $\begin{array}{l}-0.798^{* * * *} \\
(0.004)\end{array}$ & $\begin{array}{l}-0.802^{* * *} \\
(0.003)\end{array}$ & $\begin{array}{l}-1.668^{* * *} \\
(0.000)\end{array}$ & $\begin{array}{l}-1.670^{* * *} \\
(0.000)\end{array}$ & $\begin{array}{l}-1.695^{* * *} \\
(0.000)\end{array}$ \\
\hline UN voting alignment (key votes) & $\begin{array}{c}0.364 \\
(0.747)\end{array}$ & $\begin{array}{c}0.526 \\
(0.647)\end{array}$ & $\begin{array}{c}0.689 \\
(0.542)\end{array}$ & $\begin{array}{l}6.918^{* * *} \\
(0.000)\end{array}$ & $\begin{array}{l}6.911^{* * *} \\
(0.000)\end{array}$ & $\begin{array}{l}6.631^{* * *} \\
(0.000)\end{array}$ \\
\hline Commonwealth & $\begin{array}{c}0.434 \\
(0.146)\end{array}$ & $\begin{array}{c}0.464 \\
(0.132)\end{array}$ & $\begin{array}{c}0.503 \\
(0.101)\end{array}$ & $\begin{array}{l}-1.203^{* * *} \\
(0.001)\end{array}$ & $\begin{array}{l}-1.209 * * * \\
(0.001)\end{array}$ & $\begin{array}{l}-1.182^{* * *} \\
(0.001)\end{array}$ \\
\hline (log) Indian exports & $\begin{array}{l}-0.152 \\
(0.123)\end{array}$ & $\begin{array}{c}-0.157 \\
(0.117)\end{array}$ & $\begin{array}{l}-0.197^{* *} \\
(0.036)\end{array}$ & $\begin{array}{l}0.398^{* * *} \\
(0.001)\end{array}$ & $\begin{array}{l}0.400^{* * *} \\
(0.002)\end{array}$ & $\begin{array}{l}0.359 * * * \\
(0.003)\end{array}$ \\
\hline (log) Mineral and energy depletion & $\begin{array}{c}0.002 \\
(0.924)\end{array}$ & $\begin{array}{c}-0.002 \\
(0.895)\end{array}$ & $\begin{array}{l}-0.011 \\
(0.488)\end{array}$ & $\begin{array}{l}-0.019 \\
(0.339)\end{array}$ & $\begin{array}{l}-0.019 \\
(0.355)\end{array}$ & $\begin{array}{r}-0.024 \\
(0.217)\end{array}$ \\
\hline Political rights & $\begin{array}{l}-0.140 \\
(0.173)\end{array}$ & $\begin{array}{r}-0.144 \\
(0.165)\end{array}$ & $\begin{array}{l}-0.145 \\
(0.157)\end{array}$ & $\begin{array}{c}0.037 \\
(0.798)\end{array}$ & $\begin{array}{c}0.038 \\
(0.800)\end{array}$ & $\begin{array}{c}0.039 \\
(0.801)\end{array}$ \\
\hline Control of Corruption & $\begin{array}{l}-0.228 \\
(0.421)\end{array}$ & $\begin{array}{l}-0.177 \\
(0.557)\end{array}$ & $\begin{array}{l}-0.289 \\
(0.307)\end{array}$ & $\begin{array}{l}1.474^{* * *} \\
(0.000)\end{array}$ & $\begin{array}{l}1.469 * * * \\
(0.000)\end{array}$ & $\begin{array}{l}1.459 * * * \\
(0.000)\end{array}$ \\
\hline Constant & $\begin{array}{l}12.592^{* * *} \\
(0.000)\end{array}$ & $\begin{array}{l}13.075^{* * *} \\
(0.000) \\
\end{array}$ & $\begin{array}{l}11.043^{* * *} \\
(0.001)\end{array}$ & $\begin{array}{l}26.284^{* * *} \\
(0.000)\end{array}$ & $\begin{array}{l}26.253^{* * *} \\
(0.000)\end{array}$ & $\begin{array}{l}24.308^{* * *} \\
(0.000) \\
\end{array}$ \\
\hline Number of observations & 125 & 125 & 125 & 51 & 51 & 51 \\
\hline Prob $>$ Chi2 / Prob $>F$ & 0.002 & 0.000 & 0.000 & 0.000 & 0.000 & 0.000 \\
\hline (Pseudo) R-Squared & 0.17 & 0.19 & 0.18 & 0.83 & 0.82 & 0.82 \\
\hline
\end{tabular}

Note: ${ }^{*}\left({ }^{* *},{ }^{* * *}\right)$ indicates significance at the ten (five, one) percent level 
Table 2: Comparison of India's aid allocation with other donors (2008-2010)

\begin{tabular}{|c|c|c|c|c|c|c|c|}
\hline & India & USA & EU-3 & Good donors & Japan & Korea & UAE \\
\hline \multirow[t]{3}{*}{ (log) GDP per capita } & -0.249 & $-0.646 * *$ & $-0.798 * * *$ & $-1.007^{* * *}$ & $-0.586 * * *$ & $-0.562^{*}$ & $-0.926 * * *$ \\
\hline & $(0.165)$ & $(0.021)$ & $(0.000)$ & $(0.000)$ & $(0.000)$ & $(0.067)$ & $(0.007)$ \\
\hline & & 0.211 & 0.016 & 0.002 & 0.163 & 0.344 & 0.092 \\
\hline \multirow[t]{3}{*}{ (log) Affected from disasters } & $0.097 * *$ & 0.039 & -0.044 & 0.054 & $0.103^{* * *}$ & 0.045 & -0.076 \\
\hline & $(0.039)$ & $(0.500)$ & (0.358) & $(0.231)$ & $(0.007)$ & $(0.524)$ & (0.392) \\
\hline & & 0.384 & 0.013 & 0.441 & 0.925 & 0.475 & 0.101 \\
\hline \multirow[t]{3}{*}{ (log) Population } & $-0.483^{* * *}$ & $0.699 * * *$ & $0.679 * * *$ & $0.462 * * *$ & $0.371 * * *$ & $0.524 * * *$ & -0.012 \\
\hline & $(0.001)$ & $(0.000)$ & $(0.000)$ & $(0.000)$ & $(0.000)$ & $(0.004)$ & $(0.960)$ \\
\hline & & 0.000 & 0.000 & 0.000 & 0.000 & 0.000 & 0.108 \\
\hline \multirow[t]{3}{*}{ (log) Distance } & $-1.634^{* * *}$ & 0.171 & $-0.386 *$ & $-0.722 * *$ & $-1.483^{* * *}$ & -0.779 & -0.934 \\
\hline & $(0.000)$ & $(0.740)$ & $(0.081)$ & $(0.021)$ & $(0.000)$ & $(0.115)$ & (0.168) \\
\hline & & 0.002 & 0.000 & 0.033 & 0.681 & 0.123 & 0.321 \\
\hline \multirow{3}{*}{ UN voting alignment (key votes) } & $6.826 * * *$ & $2.009^{*}$ & $1.873^{*}$ & 0.165 & 0.926 & 1.923 & 2.453 \\
\hline & $(0.000)$ & $(0.077)$ & $(0.085)$ & $(0.906)$ & $(0.506)$ & $(0.627)$ & $(0.424)$ \\
\hline & & 0.006 & 0.005 & 0.001 & 0.002 & 0.236 & 0.229 \\
\hline \multirow[t]{3}{*}{ Common colonial history } & $-1.219 * * *$ & 1.221 & $1.622^{* * *}$ & $4.803^{* * *}$ & & & 0.860 \\
\hline & $(0.000)$ & $(0.465)$ & $(0.000)$ & $(0.000)$ & & & (0.191) \\
\hline & & 0.153 & 0.000 & 0.000 & & & 0.008 \\
\hline \multirow[t]{3}{*}{ (log) Bilateral exports } & $0.401 * * *$ & 0.088 & $0.367 * * *$ & 0.121 & 0.068 & $0.285^{* *}$ & $0.187^{* *}$ \\
\hline & $(0.000)$ & $(0.620)$ & $(0.004)$ & $(0.173)$ & $(0.220)$ & $(0.025)$ & (0.019) \\
\hline & & 0.118 & 0.835 & 0.025 & 0.007 & 0.444 & 0.102 \\
\hline \multirow[t]{3}{*}{ (log) Mineral and energy depletion } & -0.027 & 0.012 & 0.020 & -0.011 & -0.013 & -0.020 & -0.012 \\
\hline & $(0.115)$ & $(0.563)$ & (0.199) & $(0.591)$ & $(0.296)$ & $(0.473)$ & $(0.723)$ \\
\hline & & 0.133 & 0.017 & 0.514 & 0.498 & 0.816 & 0.691 \\
\hline \multirow[t]{3}{*}{ Political rights } & 0.056 & -0.126 & 0.068 & 0.004 & -0.012 & 0.058 & 0.058 \\
\hline & $(0.676)$ & $(0.306)$ & $(0.340)$ & $(0.967)$ & $(0.888)$ & $(0.744)$ & $(0.752)$ \\
\hline & & 0.333 & 0.939 & 0.780 & 0.677 & 0.992 & 0.993 \\
\hline \multirow[t]{3}{*}{ Control of Corruption } & $1.481 * * *$ & -0.572 & 0.202 & 0.433 & $0.467^{* *}$ & -0.273 & -0.032 \\
\hline & $(0.000)$ & $(0.188)$ & (0.438) & $(0.227)$ & $(0.045)$ & $(0.552)$ & (0.964) \\
\hline & & 0.000 & 0.001 & 0.004 & 0.003 & 0.000 & 0.051 \\
\hline Donor country dummies & Yes & Yes & Yes & Yes & Yes & Yes & Yes \\
\hline Number of observations & & & & 1371 & & & \\
\hline Number of recipients & & & & 125 & & & \\
\hline Number of recipients per donor group & 51 & 124 & 125 & 124 & 125 & 118 & 87 \\
\hline R-Squared & & & & 0.58 & & & \\
\hline
\end{tabular}

Notes:

- Estimation technique: OLS with standard errors clustered by recipient country

- Dependent variable: $(\mathrm{log})$ Aid commitments to recipient country, sum 2008-2010

- We report coefficients of the explanatory variables (corresponding $p$-values in parentheses)

- In italics: $p$-values of a Wald test of equal marginal effects of the respective donor (group) compared to India

$-*(* *, * *)$ indicates significance at the ten (five, one) percent level 
Figure 1: Aid provided by the MEA in millions of constant 2000 US\$ (1966-2010)

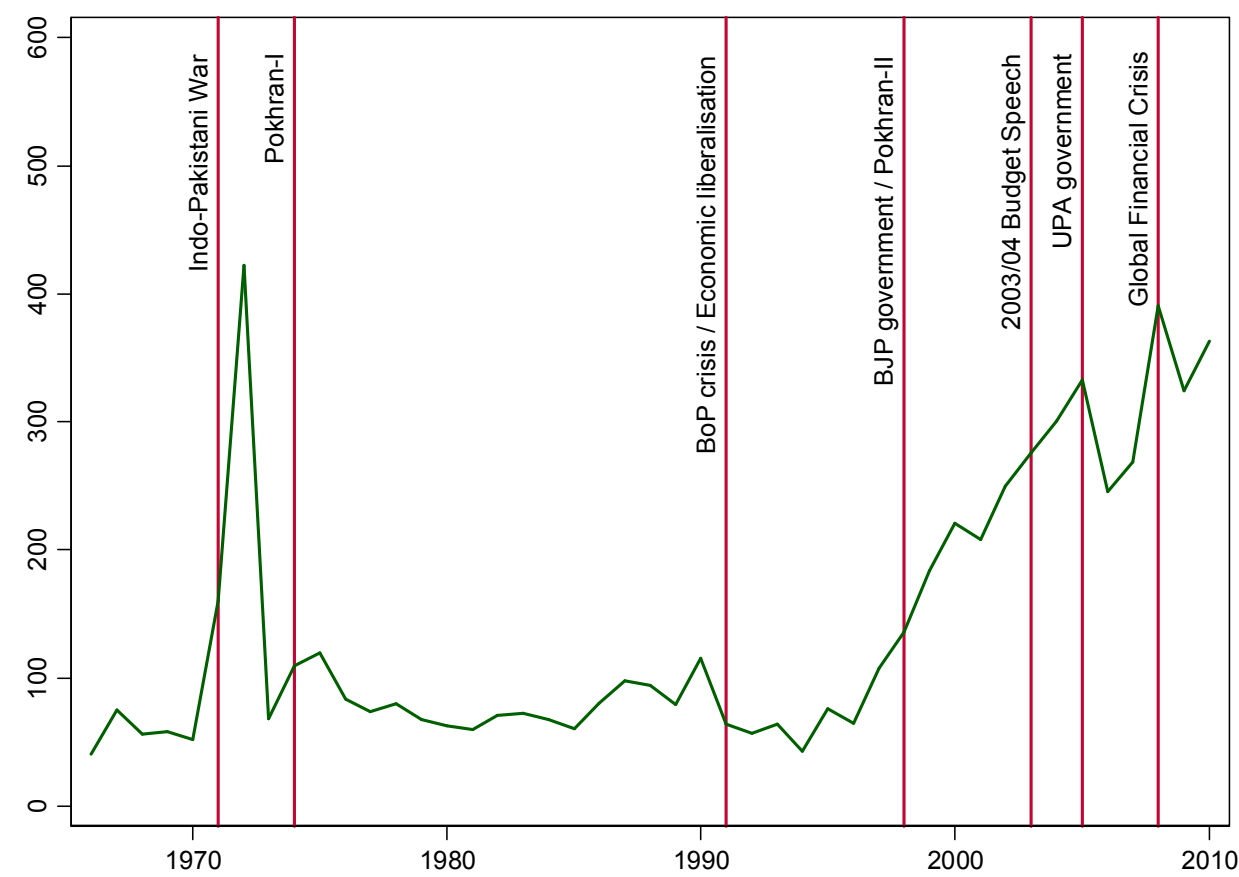

Notes: BJP: Bharatiya Janata Party; UPA: United Progressive Alliance led by Indian National Congress.

Figure 2: India's aid allocation by region (MEA, 2008-2010)

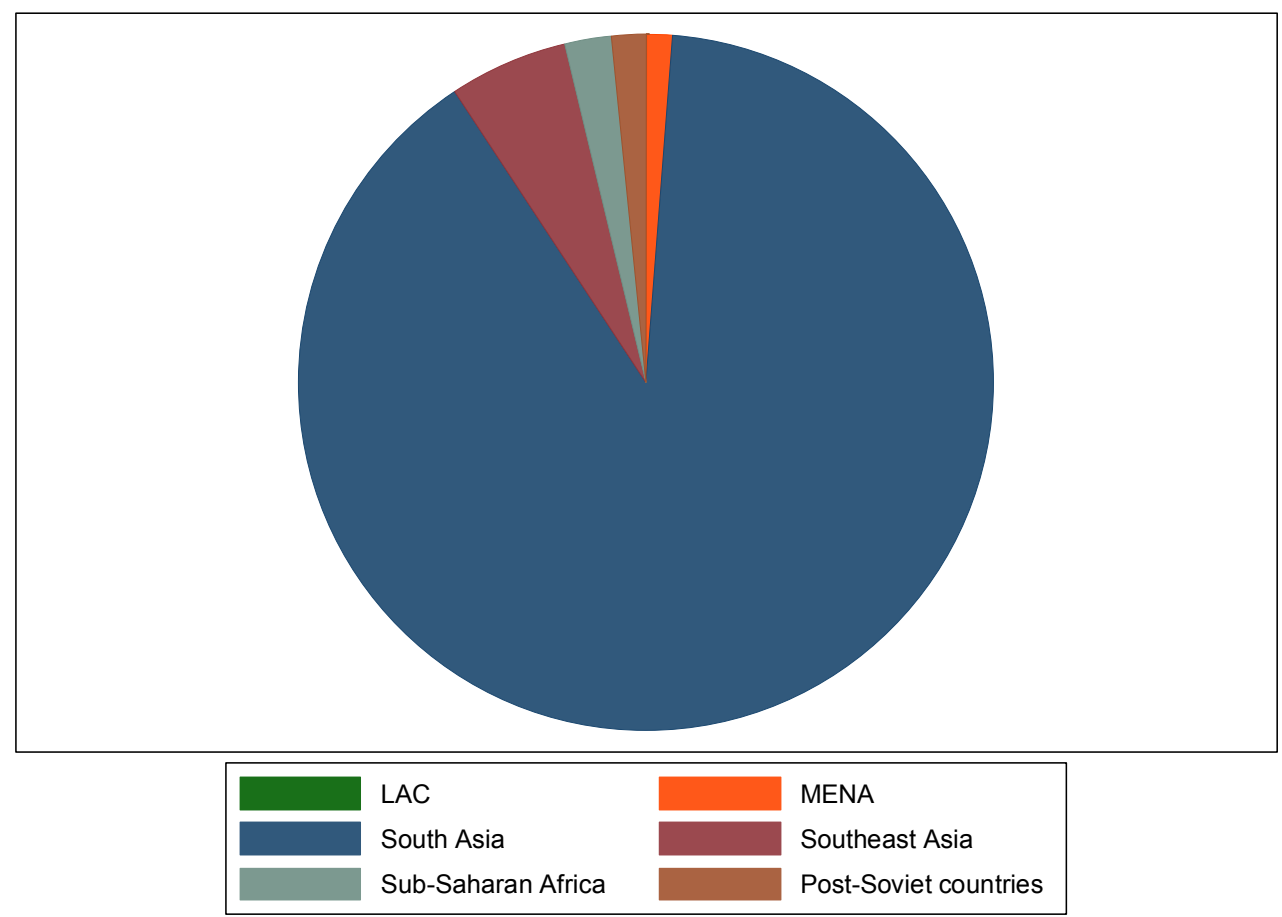


Figure 3: India's aid allocation by sector (MEA, 2008-2010)

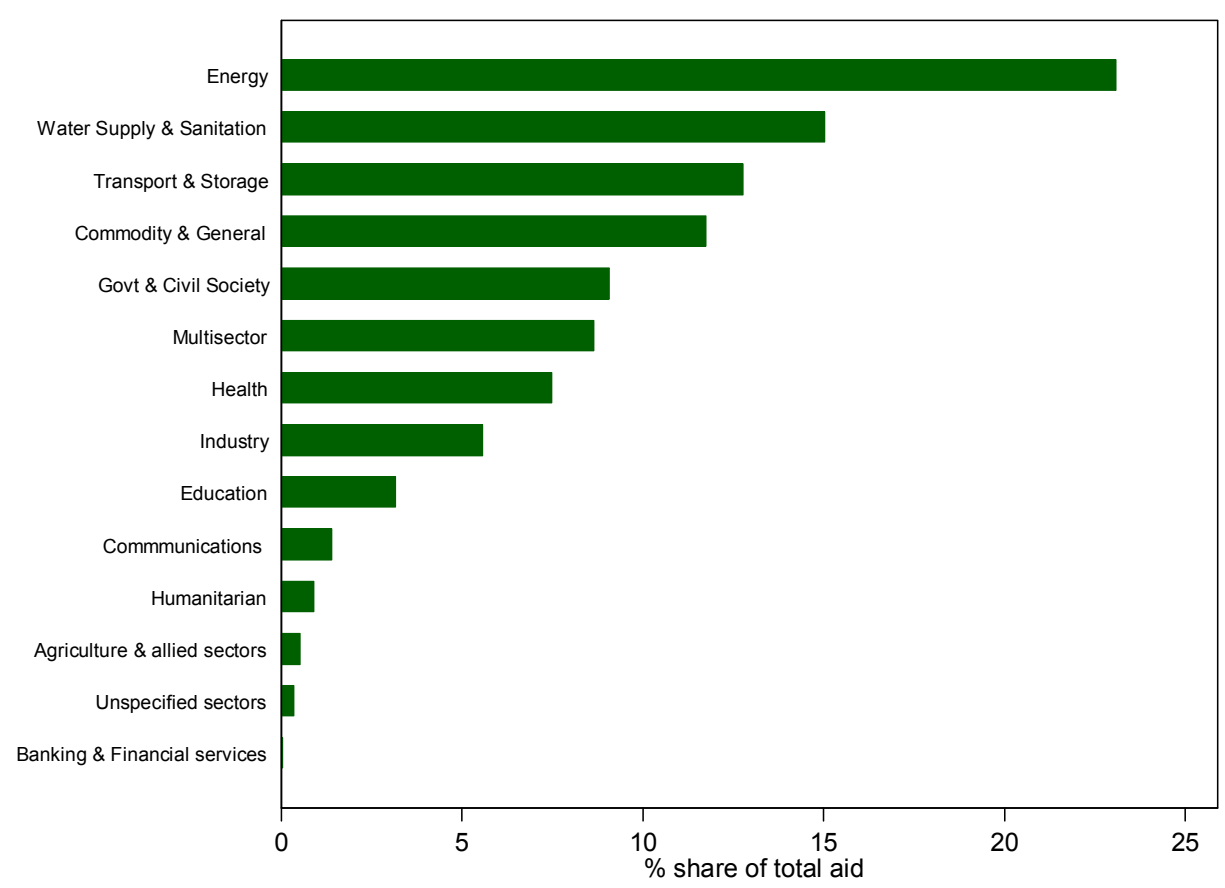

Figure 4: Aid allocation and developmental distance
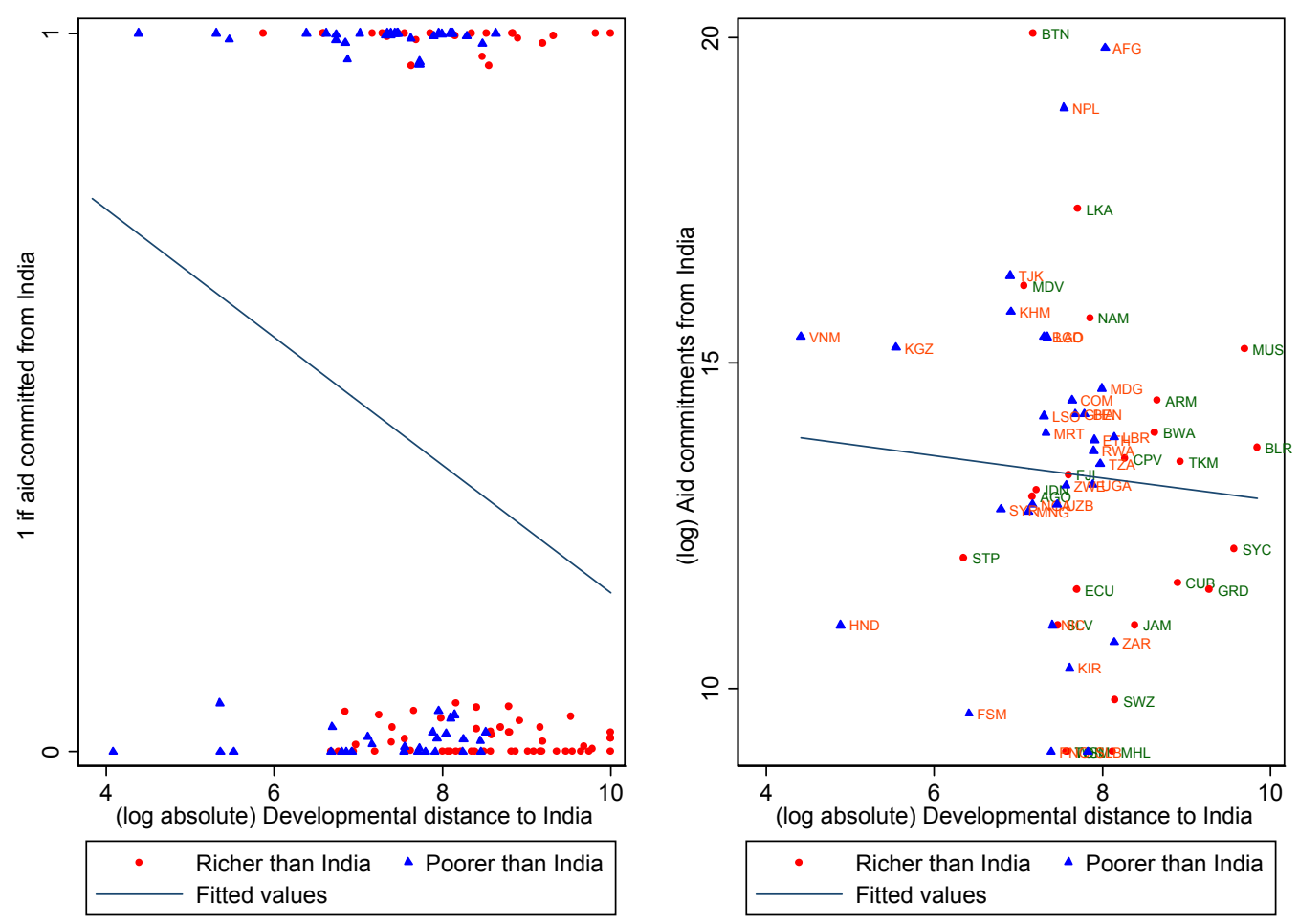
Appendix A1: Definitions and sources

\begin{tabular}{|c|c|c|}
\hline Variable & Description & Source \\
\hline \multicolumn{3}{|l|}{ Explained variables } \\
\hline $\begin{array}{l}\text { if aid commitment } \\
(\log ) \text { Aid commitment }\end{array}$ & $\begin{array}{l}1 \text { if aid commited to recipient country, 2008-2010 } \\
\text { (log) Aid commitments to recipient country (constant } 2000 \text { US\$), sum, 2008-2010 }\end{array}$ & $\begin{array}{l}\text { AidData (Findley et al. 2009) } \\
\text { AidData (Findley et al. 2009) }\end{array}$ \\
\hline \multicolumn{3}{|l|}{ Explanatory variables: Main results } \\
\hline $\begin{array}{l}(\log ) \text { GDP per capita } \\
(\log ) \text { Developmental distance } \\
(\log ) \text { Affected from disasters } \\
(\log ) \text { Population } \\
(\text { log) Distance } \\
\text { UN voting alignment (key votes) } \\
\text { Commonwealth } \\
\text { Common colonial history } \\
(\text { log) Indian/Bilateral exports } \\
(\text { log) Mineral and energy depletion } \\
\text { Political rights } \\
\text { Control of corruption }\end{array}$ & $\begin{array}{l}\text { (log) GDP per capita (constant } 2005 \text { I\$), lag } \\
\text { (log) Absolute difference between the per-capita GDP of donor and recipient, lag } \\
\text { (log) Number of people affected by disasters, average } \\
\text { (log) Total population, lag } \\
\text { (log) Bilateral distance (weighted by populations of major cities) } \\
\text { UNGA voting alignment between donor and recipient (key votes), lag } \\
1 \text { if recipient is a non-suspended member of the Commonwealth, lag } \\
1 \text { if donor and recipient have had a colonial relationship or a common colonizer after } 1945 \\
\text { (log) Total exports from donor to recipient country, lag } \\
\text { (log) Product of unit resource rents and physical quantities of energy and minerals extracted, lag } \\
\text { Index of political rights rated on a seven-point scale (1: most free), lag } \\
\text { Index ranging from }-2.5 \text { to } 2.5 \text { with higher values corresponding to better governance, lag }\end{array}$ & $\begin{array}{l}\text { Penn World Tables (Heston et al. 2009) } \\
\text { Own construction based on Penn World Tables } \\
\text { EM-DAT (2010) } \\
\text { Penn World Tables (Heston et al. 2009) } \\
\text { CEPII (Mayer and Zignago 2006) } \\
\text { Voeten and Merdzanovic (2009), Kilby (2009) } \\
\text { www.thecommonwealth.org, internet research } \\
\text { CEPII (Mayer and Zignago 2006) } \\
\text { UN Comtrade via WITS (http://wits.worldbank.org) } \\
\text { World Bank (http://data.worldbank.org/indicator) } \\
\text { Freedom House (2009) } \\
\text { Kaufmann et al. (2009) }\end{array}$ \\
\hline \multicolumn{3}{|c|}{ Explanatory variables: Robustness checks } \\
\hline$(\log )$ Indian migrants (definition 1) & (log) India & Global Migrant Origin Database (Parsons et al. 2007) \\
\hline (log) Indian migrants (definition 2) & (log) Estimated size of Indian community in recipient country, 2001 & MEA (2001b) \\
\hline Chinese aid projects & Number of Chinese aid projects completed in recipient country (\% of total), 1996-2005 & Dreher and Fuchs (2011) \\
\hline (log) Under-5 mortality Rate & (log) Mortality rate, under 5 years (per 1000), lag & World Bank (http://data.worldbank.org/indicator) \\
\hline Neighbor & 1 if donor and recipient share a border & CEPII (Mayer and Zignago 2006) \\
\hline UN voting alignment & UNGA voting alignment between donor and recipient, lag & Voeten and Merdzanovic (2009), Kilby (2009) \\
\hline UN voting alignment (BRIC vs USA) & UNGA voting alignment between donor and recipient (disagreement between BRIC and USA), Iag & Voeten and Merdzanovic (2009), Kilby (2009) \\
\hline Common language & 1 if $e$ if a language is spoken by at least $9 \%$ of the population in donor and recipient country & CEPII (Mayer and Zignago 2006) \\
\hline Democracy & 1 if the regime qualifies as democratic, lag & Cheibub et al. (2010) \\
\hline
\end{tabular}

Notes:

- Values in current US\$ have been transformed to constant 2000 US\$ using US Consumer Price Indices from the World Bank (http://data.worldbank.org/indicator)

- The value of 1 has been added to exports and natural resource variables as well as to the number of people affected by disasters before taking logarithms 
Appendix A2: Descriptive statistics

\begin{tabular}{l|cccccc|} 
& Obs & Mean & Std. Dev. & Min & Max \\
\hline 1 if aid commitment & 125 & 0.41 & 0.49 & 0.00 & 1.00 \\
(log) Aid commitment & 51 & 13.28 & 2.45 & 9.02 & 20.07 \\
\hline (log) GDP per capita & 125 & 8.37 & 0.97 & 5.95 & 10.16 \\
Control of Corruption & 125 & 7.86 & 1.09 & 3.83 & 10.00 \\
(log) Affected from disasters & 125 & 9.21 & 4.34 & 0.00 & 18.71 \\
(log) Population & 125 & 15.62 & 2.02 & 10.59 & 21.00 \\
(log) Distance & 125 & 8.83 & 0.64 & 7.04 & 9.74 \\
UN voting alignment (key votes) & 125 & 0.74 & 0.14 & 0.25 & 0.93 \\
Commonwealth & 125 & 0.30 & 0.46 & 0.00 & 1.00 \\
Common colonial history & 125 & 0.30 & 0.46 & 0.00 & 1.00 \\
(log) Mineral and energy depletion & 125 & 13.16 & 10.22 & 0.00 & 25.82 \\
Political rights & 125 & 3.94 & 1.95 & 1.00 & 7.00 \\
Control of Corruption & 125 & -0.47 & 0.59 & -1.38 & 1.34 \\
\hline (log) Indian migrants (definition 1) & 125 & 6.17 & 2.99 & 0.00 & 13.86 \\
(log) Indian migrants (definition 2) & 125 & 4.73 & 4.24 & 0.00 & 14.33 \\
Chinese project aid & 124 & 0.75 & 0.94 & 0.00 & 4.62 \\
(log) Under-5 mortality Rate & 125 & 3.84 & 0.90 & 1.76 & 5.57 \\
Neighbor & 125 & 0.04 & 0.20 & 0.00 & 1.00 \\
UN Voting alignment & 125 & 0.79 & 0.10 & 0.38 & 0.89 \\
UN Voting alignment (BRIC vs USA) & 125 & 0.92 & 0.12 & 0.37 & 1.00 \\
Common language & 125 & 0.31 & 0.47 & 0.00 & 1.00 \\
Democracy & 125 & 0.52 & 0.50 & 0.00 & 1.00 \\
\hline
\end{tabular}

Note: Descriptive statistics for sample as in Table 1, column 1 
Appendix B1: Allocation of India's aid commitments (Probit, 2008-2010): Robustness checks

\begin{tabular}{|c|c|c|c|c|c|c|c|c|c|c|c|}
\hline & baseline & (1a) & (1b) & (2) & (3) & (4) & (5) & (6) & (7) & (8) & (9) \\
\hline (log) GDP per capita & $\begin{array}{l}-0.315^{*} \\
(0.060)\end{array}$ & $\begin{array}{l}-0.308^{*} \\
(0.067)\end{array}$ & $\begin{array}{l}-0.313^{*} \\
(0.0611\end{array}$ & $\begin{array}{l}-0.247 \\
(0.165)\end{array}$ & $\begin{array}{l}-0.469 * * \\
(0.037)\end{array}$ & $\begin{array}{l}-0.315^{*} \\
(0.059)\end{array}$ & $\begin{array}{l}-0.316^{*} \\
(0.057)\end{array}$ & $\begin{array}{c}-0.321^{*} \\
(0.053)\end{array}$ & $\begin{array}{c}-0.331^{*} \\
(0.052)\end{array}$ & $\begin{array}{l}-0.320^{*} \\
(0.059)\end{array}$ & $\begin{array}{l}-0.319^{*} \\
(0.054)\end{array}$ \\
\hline (log) Affected from disasters & -0.060 & -0.057 & -0.060 & -0.066 & -0.058 & -0.060 & -0.062 & -0.060 & -0.058 & -0.058 & -0.053 \\
\hline & (0.137) & $(0.170)$ & $(0.139)$ & $(0.102)$ & $(0.145)$ & $(0.134)$ & $(0.128)$ & $(0.139)$ & $(0.151)$ & $(0.152)$ & $(0.177)$ \\
\hline (log) Population & 0.028 & 0.015 & 0.031 & 0.062 & 0.007 & 0.028 & 0.022 & 0.028 & -0.027 & -0.009 & 0.016 \\
\hline & $(0.852)$ & $(0.924)$ & $(0.837)$ & $(0.681)$ & $(0.963)$ & $(0.852)$ & $(0.883)$ & $(0.850)$ & $(0.854)$ & $(0.950)$ & $(0.914)$ \\
\hline (log) Distance & $-0.847^{* * *}$ & $-0.806^{* * *}$ & $-0.847 * *$ & $-0.783^{* * *}$ & $-0.825^{* * *}$ & $-0.841^{* * *}$ & $-0.873^{* * *}$ & $-0.850^{* * *}$ & $-0.852^{* * *}$ & $-0.852^{2 * *}$ & $-0.797^{* * *}$ \\
\hline & $(0.001)$ & $(0.004)$ & $(0.001)$ & $(0.003)$ & $(0.002)$ & $(0.003)$ & $(0.001)$ & $(0.001)$ & $(0.001)$ & $(0.001)$ & $(0.001)$ \\
\hline UN voting alignment (key votes) & 0.364 & 0.375 & 0.337 & 0.157 & 0.610 & 0.365 & & & 0.602 & 0.530 & 0.380 \\
\hline & $(0.747)$ & $(0.738)$ & $(0.767)$ & $(0.889)$ & $(0.590)$ & $(0.746)$ & & & $(0.590)$ & $(0.641)$ & $(0.727)$ \\
\hline Commonwealth & 0.434 & 0.408 & 0.424 & 0.432 & 0.494 & 0.432 & 0.436 & 0.448 & & & $0.549^{*}$ \\
\hline & (0.146) & $(0.169)$ & $(0.162)$ & $(0.150)$ & $(0.100)$ & $(0.146)$ & $(0.140)$ & $(0.128)$ & & & $(0.061)$ \\
\hline (log) Indian exports & -0.152 & -0.166 & -0.157 & $-0.165^{*}$ & -0.148 & -0.152 & -0.162 & -0.144 & -0.126 & -0.136 & -0.152 \\
\hline & $(0.123)$ & $(0.102)$ & $(0.128)$ & $(0.092)$ & $(0.135)$ & $(0.124)$ & $(0.101)$ & $(0.137)$ & (0.197) & $(0.166)$ & $(0.121)$ \\
\hline (log) Mineral and energy depletion & 0.002 & 0.002 & 0.001 & 0.001 & 0.003 & 0.002 & 0.002 & 0.002 & 0.003 & 0.003 & 0.003 \\
\hline & (0.924) & $(0.908)$ & $(0.948)$ & $(0.940)$ & $(0.885)$ & $(0.923)$ & $(0.896)$ & $(0.920)$ & $(0.877)$ & $(0.864)$ & $(0.852)$ \\
\hline Political rights & -0.140 & -0.136 & -0.139 & -0.133 & -0.135 & -0.140 & -0.142 & -0.131 & -0.163 & -0.162 & \\
\hline & $(0.173)$ & $(0.184)$ & $(0.175)$ & $(0.201)$ & $(0.190)$ & $(0.173)$ & $(0.153)$ & $(0.171)$ & $(0.124)$ & $(0.116)$ & \\
\hline Control of Corruption & -0.228 & -0.237 & -0.231 & -0.211 & -0.315 & -0.230 & -0.250 & -0.212 & $\begin{array}{l}-0.205 \\
-0.267)\end{array}$ & -0.219 & $\begin{array}{r}-0.114 \\
-0670\end{array}$ \\
\hline (log) Indian migrants (definition 2) & $(0.421)$ & $\frac{(0.404)}{0.026}$ & $(0.415)$ & $(0.452)$ & $(0.291)$ & $(0.423)$ & $(0.378)$ & $(0.450)$ & $(0.467)$ & $(0.440)$ & $(0.670)$ \\
\hline & & $(0.662)$ & & & & & & & & & \\
\hline (log) Indian migrants (definition 2) & & & $\begin{array}{c}0.005 \\
(0.883)\end{array}$ & & & & & & & & \\
\hline Chinese project aid & & & & $\begin{array}{c}0.190 \\
(0.174)\end{array}$ & & & & & & & \\
\hline (log) Under-5 mortality Rate & & & & & $\begin{array}{l}-0.246 \\
(0.291)\end{array}$ & & & & & & \\
\hline Neighbor & & & & & & $\begin{array}{c}0.035 \\
(0.961)\end{array}$ & & & & & \\
\hline UN voting alignment & & & & & & & $\begin{array}{c}0.978 \\
(0.492)\end{array}$ & & & & \\
\hline UN voting alignment (BRIC vs USA) & & & & & & & & $\begin{array}{c}0.073 \\
(0.950)\end{array}$ & & & \\
\hline Common language & & & & & & & & & $\begin{array}{c}0.039 \\
(0.894)\end{array}$ & & \\
\hline Colonial relationship & & & & & & & & & & $\begin{array}{c}0.148 \\
(0.624)\end{array}$ & \\
\hline Democracy & & & & & & & & & & & 0.442 \\
\hline Constant & $\begin{array}{l}12.592^{* * *} \\
(0.000)\end{array}$ & $\begin{array}{l}12.416^{* * *} \\
(0.000)\end{array}$ & $\begin{array}{l}12.632 * * * \\
(0.000)\end{array}$ & $\begin{array}{l}11.210^{* * *} \\
(0.002)\end{array}$ & $\begin{array}{l}14.607^{* * *} \\
(0.000)\end{array}$ & $\begin{array}{l}12.546^{* * *} \\
(0.000)\end{array}$ & $\begin{array}{l}12.617^{* * *} \\
(0.000)\end{array}$ & $\begin{array}{l}12.704 * * * \\
(0.000)\end{array}$ & $\begin{array}{l}13.218^{* * *} \\
(0.000)\end{array}$ & $\begin{array}{l}13.031^{* * *} \\
(0.000)\end{array}$ & $\begin{array}{l}(0.133) \\
11.524^{* * *} \\
(0.000)\end{array}$ \\
\hline Number of observations & $\frac{0.03}{125}$ & 125 & 125 & 124 & 125 & 125 & $\frac{1000}{125}$ & 125 & 125 & 125 & 125 \\
\hline Prob>Chi2 & 0.002 & 0.003 & 0.003 & 0.003 & 0.001 & 0.003 & 0.002 & 0.002 & 0.002 & 0.002 & 0.002 \\
\hline Pseudo R-Squared & 0.17 & 0.17 & 0.17 & 0.18 & 0.18 & 0.17 & 0.17 & 0.17 & 0.16 & 0.16 & 0.17 \\
\hline
\end{tabular}

Notes: ${ }^{* * * * * *}$ indicates significance at the ten (five, one) percentlevel

- Dependent variable: Dummy variable that takes a value of one if aid was commited to a recipient country during the 2008-2010 period 
Appendix B2: Allocation of India's aid commitments (OLS, 2008-2010): Robustness checks

\begin{tabular}{|c|c|c|c|c|c|c|c|c|c|c|c|}
\hline & baseline & (1a) & (1b) & (2) & (3) & (4) & (5) & (6) & (7) & (8) & (9) \\
\hline (log) GDP per capita & $\begin{array}{r}-0.241 \\
(0.226)\end{array}$ & $\begin{array}{r}-0.235 \\
(0.251)\end{array}$ & $\begin{array}{r}-0.240 \\
(0.233)\end{array}$ & $\begin{array}{r}-0.214 \\
(0.292)\end{array}$ & $\begin{array}{r}-0.047 \\
(0.880)\end{array}$ & $\begin{array}{r}-0.230 \\
(0.246)\end{array}$ & $\begin{array}{r}-0.317 \\
(0.126)\end{array}$ & $\begin{array}{r}-0.286 \\
(0.175)\end{array}$ & $\begin{array}{r}-0.233 \\
(0.340)\end{array}$ & $\begin{array}{r}-0.249 \\
(0.208)\end{array}$ & $\begin{array}{r}-0.251 \\
(0.201)\end{array}$ \\
\hline (log) Affected from disasters & $\begin{array}{l}0.111^{* *} \\
(0.037)\end{array}$ & $\begin{array}{c}0.112^{* *} \\
(0.041)\end{array}$ & $\begin{array}{l}0.111^{* *} \\
(0.040)\end{array}$ & $\begin{array}{c}0.109 * * \\
(0.042)\end{array}$ & $\begin{array}{l}0.106^{* *} \\
(0.034)\end{array}$ & $\begin{array}{l}0.108^{* *} \\
(0.043)\end{array}$ & $\begin{array}{r}0.077 \\
(0.162)\end{array}$ & $\begin{array}{r}0.075 \\
(0.173)\end{array}$ & $\begin{array}{c}0.101^{*} \\
(0.060)\end{array}$ & $\begin{array}{c}0.097 * \\
(0.063)\end{array}$ & $\begin{array}{l}0.110^{* *} \\
(0.036)\end{array}$ \\
\hline (log) Population & $\begin{array}{l}-0.526^{* * *} \\
(0.002)\end{array}$ & $\begin{array}{l}-0.533^{* * *} \\
(0.004)\end{array}$ & $\begin{array}{l}-0.526^{* * *} \\
(0.002)\end{array}$ & $\begin{array}{l}-0.531^{* * *} \\
(0.003)\end{array}$ & $\begin{array}{l}-0.532^{* * *} \\
(0.003)\end{array}$ & $\begin{array}{l}-0.522^{* * *} \\
(0.002)\end{array}$ & $\begin{array}{l}-0.502^{* * *} \\
(0.003)\end{array}$ & $\begin{array}{l}-0.465 * * * \\
(0.008)\end{array}$ & $\begin{array}{l}-0.363 * * \\
(0.037)\end{array}$ & $\begin{array}{l}-0.483^{* * *} \\
(0.004)\end{array}$ & $\begin{array}{l}-0.542^{* * *} \\
(0.003)\end{array}$ \\
\hline (log) Distance & $-1.668 * * *$ & $-1.646^{* * *}$ & $-1.669 * * *$ & $-1.630^{* * *}$ & $-1.660^{* * *}$ & $-1.529 * * *$ & $-1.997 * *$ & $-2.053^{* * *}$ & $-1.857^{* * *}$ & $-1.634^{* * *}$ & $-1.635 * * *$ \\
\hline UN voting alignment (key votes) & $\begin{array}{l}(0.000) \\
6.918^{* * *}\end{array}$ & $\begin{array}{l}(0.000) \\
6.968^{* * *}\end{array}$ & $\begin{array}{l}(0.000) \\
6.907 * *\end{array}$ & $\begin{array}{l}(0.000) \\
6.933^{* * *}\end{array}$ & $\begin{array}{l}(0.000) \\
6.858^{* * *}\end{array}$ & $\begin{array}{l}(0.000) \\
7.215^{* * *}\end{array}$ & $(0.000)$ & $(0.000)$ & $\begin{array}{l}(0.000) \\
5.926^{* * *}\end{array}$ & $\begin{array}{l}(0.000) \\
6.826^{* * *}\end{array}$ & $\begin{array}{l}(0.000) \\
6.941^{* * *}\end{array}$ \\
\hline & $\begin{array}{l}(0.000) \\
-1.203 * *\end{array}$ & $\begin{array}{l}(0.000) \\
-1.214^{* * *}\end{array}$ & $\begin{array}{l}(0.000) \\
-1.210^{* * *}\end{array}$ & $\begin{array}{l}(0.000) \\
-1.210^{* * *}\end{array}$ & $\begin{array}{l}(0.000) \\
-1.236^{* * *}\end{array}$ & $\begin{array}{l}(0.000) \\
-1.199 * *\end{array}$ & $-1.050^{* * *}$ & $-1.000^{* * *}$ & $(0.000)$ & $(0.000)$ & $\begin{array}{l}(0.000) \\
-1.292 * * *\end{array}$ \\
\hline Commonwealth & $(0.001)$ & $(0.002)$ & $(0.002)$ & $(0.001)$ & $(0.001)$ & $(0.001)$ & $(0.003)$ & $(0.006)$ & & & $(0.000)$ \\
\hline (log) Indian exports & $\begin{array}{l}0.398 * * \\
(0.001)\end{array}$ & $\begin{array}{l}0.394 * * \\
(0.001)\end{array}$ & $\begin{array}{l}0.395 * * \\
(0.001)\end{array}$ & $\begin{array}{l}0.398 * * * \\
(0.001)\end{array}$ & $\begin{array}{l}0.411^{* * *} \\
(0.001)\end{array}$ & $\begin{array}{l}0.383^{* * *} \\
(0.002)\end{array}$ & $\begin{array}{l}0.365 * * * \\
(0.003)\end{array}$ & $\begin{array}{l}0.377^{* * *} \\
(0.003)\end{array}$ & $\begin{array}{l}0.292 * * \\
(0.015)\end{array}$ & $\begin{array}{l}0.401 * * \\
(0.001)\end{array}$ & $\begin{array}{l}0.412 * * \\
(0.002)\end{array}$ \\
\hline (log) Mineral and energy depletion & $\begin{array}{r}-0.019 \\
(0.339)\end{array}$ & $\begin{array}{r}-0.019 \\
(0.325)\end{array}$ & $\begin{array}{r}-0.019 \\
(0.316)\end{array}$ & $\begin{array}{r}-0.019 \\
(0.350)\end{array}$ & $\begin{array}{r}-0.019 \\
(0.349)\end{array}$ & $\begin{array}{r}-0.019 \\
(0.347)\end{array}$ & $\begin{array}{r}-0.010 \\
(0.625)\end{array}$ & $\begin{array}{r}-0.011 \\
(0.622)\end{array}$ & $\begin{array}{r}-0.014 \\
(0.534)\end{array}$ & $\begin{array}{r}-0.027 \\
(0.153)\end{array}$ & $\begin{array}{r}-0.020 \\
(0.303)\end{array}$ \\
\hline Political rights & $\begin{array}{r}0.037 \\
(0.798)\end{array}$ & $\begin{array}{r}0.038 \\
(0.797)\end{array}$ & $\begin{array}{r}0.037 \\
(0.802)\end{array}$ & $\begin{array}{r}0.039 \\
(0.788)\end{array}$ & $\begin{array}{r}0.030 \\
(0.849)\end{array}$ & $\begin{array}{r}0.035 \\
(0.812)\end{array}$ & $\begin{array}{r}0.072 \\
(0.568)\end{array}$ & $\begin{array}{r}0.096 \\
(0.447)\end{array}$ & $\begin{array}{r}0.052 \\
(0.750)\end{array}$ & $\begin{array}{r}0.056 \\
(0.703)\end{array}$ & \\
\hline Control of Corruption & $\begin{array}{l}1.474^{* * *} \\
(0.000)\end{array}$ & $\begin{array}{l}1.473^{* * *} \\
(0.000)\end{array}$ & $\begin{array}{l}1.470^{* * *} \\
(0.000)\end{array}$ & $\begin{array}{l}1.465 * * * \\
(0.000)\end{array}$ & $\begin{array}{l}1.426^{* * *} \\
(0.000)\end{array}$ & $\begin{array}{l}1.403^{* * *} \\
(0.000)\end{array}$ & $\begin{array}{l}1.508^{* * *} \\
(0.000)\end{array}$ & $\begin{array}{l}1.587^{* * *} \\
(0.000)\end{array}$ & $\begin{array}{l}1.505^{* * *} \\
(0.000)\end{array}$ & $\begin{array}{l}1.481^{* * *} \\
(0.000)\end{array}$ & $\begin{array}{l}1.461^{* * *} \\
(0.000)\end{array}$ \\
\hline (log) Indian migrants (definition 1) & & $\begin{array}{c}0.011 \\
(0.892)\end{array}$ & & & & & & & & & \\
\hline (log) Indian migrants (definition 2) & & & $\begin{array}{c}0.004 \\
(0.920)\end{array}$ & & & & & & & & \\
\hline Chinese project aid & & & & $\begin{array}{c}0.080 \\
(0.551)\end{array}$ & & & & & & & \\
\hline (log) Under-5 mortality Rate & & & & & $\begin{array}{c}0.341 \\
(0.267)\end{array}$ & & & & & & \\
\hline Neighbor & & & & & & $\begin{array}{c}0.682 \\
(0.268)\end{array}$ & & & & & \\
\hline UN voting alignment & & & & & & & $\begin{array}{l}8.478^{* * *} \\
(0.000)\end{array}$ & & & & \\
\hline UN voting alignment (BRIC vs USA) & & & & & & & & $\begin{array}{l}5.854^{* * *} \\
(0.000)\end{array}$ & & & \\
\hline Common language & & & & & & & & & $\begin{array}{r}-0.239 \\
(0.486)\end{array}$ & & \\
\hline Common colonial history & & & & & & & & & & $\begin{array}{l}-1.219^{* * *} \\
(0.001)\end{array}$ & \\
\hline Democracy & & & & & & & & & & & $\begin{array}{l}-0.259 \\
(0.498)\end{array}$ \\
\hline Constant & $\begin{array}{l}26.284 * * * \\
(0.000)\end{array}$ & $\begin{array}{l}26.111 * * * \\
(0.000)\end{array}$ & $\begin{array}{l}26.321^{* * *} \\
(0.000)\end{array}$ & $\begin{array}{l}25.727^{* * *} \\
(0.000)\end{array}$ & $\begin{array}{l}23.238^{* * *} \\
(0.000)\end{array}$ & $\begin{array}{l}24.922^{* * *} \\
(0.000)\end{array}$ & $\begin{array}{l}28.461^{* * *} \\
(0.000)\end{array}$ & $\begin{array}{l}29.206^{* * *} \\
(0.000)\end{array}$ & $\begin{array}{l}27.4866^{* * *} \\
(0.000)\end{array}$ & $\begin{array}{l}25.511^{* * *} \\
(0.000)\end{array}$ & $\begin{array}{l}26.396^{* * *} \\
(0.000)\end{array}$ \\
\hline $\begin{array}{l}\text { Number of observations } \\
\text { Prob>F }\end{array}$ & $\begin{array}{c}51 \\
0.000\end{array}$ & $\begin{array}{c}51 \\
0.000\end{array}$ & $\begin{array}{c}51 \\
0.000\end{array}$ & $\begin{array}{c}51 \\
0.000\end{array}$ & $\begin{array}{c}51 \\
0.000\end{array}$ & $\begin{array}{c}51 \\
0.000\end{array}$ & $\begin{array}{c}51 \\
0.000\end{array}$ & $\begin{array}{c}51 \\
0.000\end{array}$ & $\begin{array}{c}51 \\
0.000\end{array}$ & $\begin{array}{c}51 \\
0.000\end{array}$ & $\begin{array}{c}51 \\
0.000\end{array}$ \\
\hline R-Squared & 0.83 & 0.82 & 0.82 & 0.82 & 0.83 & 0.83 & 0.84 & 0.84 & 0.77 & 0.83 & 0.83 \\
\hline
\end{tabular}

* ${ }^{* * * * * * *)}$ indicates significance at the ten (five, one) percentlevel

Dependent variabe: (log) Aid commitments to recipient country sum 2008-2010 
Appendix B3: Comparison of India's aid allocation with other donors

(Indian aid recipients only, 2008-2010)

\begin{tabular}{|c|c|c|c|c|c|c|c|}
\hline & India & USA & EU-3 & Good donors & Japan & Korea & UAE \\
\hline \multirow[t]{3}{*}{ (log) GDP per capita } & -0.249 & 0.003 & $-0.628^{* *}$ & $-0.647^{* *}$ & -0.314 & -0.237 & $-1.174^{* *}$ \\
\hline & (0.191) & (0.994) & $(0.035)$ & (0.011) & (0.108) & $(0.429)$ & $(0.027)$ \\
\hline & & 0.552 & 0.203 & 0.154 & 0.823 & 0.970 & 0.119 \\
\hline \multirow[t]{3}{*}{ (log) Affected from disasters } & $0.097^{*}$ & $0.131^{*}$ & 0.025 & 0.062 & $0.083^{*}$ & 0.099 & -0.213 \\
\hline & $(0.053)$ & $(0.083)$ & $(0.705)$ & $(0.342)$ & $(0.056)$ & $(0.278)$ & $(0.188)$ \\
\hline & & 0.696 & 0.244 & 0.595 & 0.844 & 0.979 & 0.073 \\
\hline \multirow[t]{3}{*}{ (log) Population } & $-0.483^{* * *}$ & $0.868^{* * *}$ & $0.543^{* *}$ & $0.567^{* * *}$ & $0.312^{* *}$ & $0.841 * * *$ & -0.256 \\
\hline & $(0.002)$ & $(0.005)$ & $(0.013)$ & $(0.001)$ & $(0.020)$ & $(0.000)$ & $(0.507)$ \\
\hline & & 0.000 & 0.000 & 0.000 & 0.000 & 0.000 & 0.601 \\
\hline \multirow[t]{3}{*}{ (log) Distance } & $-1.634^{* * *}$ & 0.184 & -0.535 & $-1.139 * *$ & $-1.467^{* * *}$ & $-1.336^{* * *}$ & $-2.001 *$ \\
\hline & $(0.000)$ & $(0.798)$ & $(0.317)$ & $(0.022)$ & $(0.000)$ & $(0.002)$ & $(0.072)$ \\
\hline & & 0.025 & 0.041 & 0.394 & 0.618 & 0.544 & 0.739 \\
\hline \multirow[t]{3}{*}{ UN voting alignment (key votes) } & $6.826 * * *$ & 4.023 & -0.383 & 0.717 & -0.076 & $10.602^{* *}$ & -1.883 \\
\hline & $(0.000)$ & $(0.165)$ & $(0.880)$ & $(0.766)$ & $(0.964)$ & $(0.016)$ & $(0.678)$ \\
\hline & & 0.389 & 0.021 & 0.030 & 0.001 & 0.388 & 0.097 \\
\hline \multirow[t]{3}{*}{ Common colonial history } & $-1.219 * * *$ & $4.189 * * *$ & $1.039 * *$ & $2.681^{* * *}$ & & & 0.606 \\
\hline & $(0.000)$ & $(0.007)$ & $(0.050)$ & $(0.000)$ & & & (0.519) \\
\hline & & 0.001 & 0.000 & 0.000 & & & 0.092 \\
\hline \multirow[t]{3}{*}{ (log) Bilateral exports } & $0.401 * * *$ & 0.043 & $0.506^{* * *}$ & $0.311^{* * *}$ & $0.220 * * *$ & $0.217^{*}$ & $0.231^{* *}$ \\
\hline & $(0.001)$ & $(0.858)$ & (0.009) & $(0.002)$ & $(0.003)$ & $(0.074)$ & $(0.014)$ \\
\hline & & 0.136 & 0.616 & 0.468 & 0.179 & 0.184 & 0.226 \\
\hline \multirow[t]{3}{*}{ (log) Mineral and energy depletion } & -0.027 & 0.037 & 0.012 & -0.030 & -0.019 & -0.031 & 0.020 \\
\hline & $(0.137)$ & $(0.253)$ & $(0.630)$ & $(0.291)$ & $(0.164)$ & $(0.222)$ & (0.618) \\
\hline & & 0.066 & 0.084 & 0.926 & 0.716 & 0.914 & 0.301 \\
\hline \multirow[t]{3}{*}{ Political rights } & 0.056 & -0.026 & 0.083 & 0.141 & -0.052 & 0.186 & -0.499 \\
\hline & $(0.692)$ & $(0.897)$ & $(0.410)$ & $(0.251)$ & $(0.474)$ & $(0.177)$ & $(0.190)$ \\
\hline & & 0.756 & 0.881 & 0.697 & 0.491 & 0.468 & 0.200 \\
\hline \multirow[t]{3}{*}{ Control of Corruption } & $1.481 * * *$ & 0.175 & $0.972^{* *}$ & $1.321^{* * *}$ & $0.573^{* *}$ & -0.267 & -1.157 \\
\hline & $(0.000)$ & $(0.805)$ & $(0.021)$ & $(0.005)$ & $(0.048)$ & $(0.607)$ & $(0.398)$ \\
\hline & & 0.094 & 0.314 & 0.707 & 0.025 & 0.001 & 0.064 \\
\hline Donor country dummies & Yes & Yes & Yes & Yes & Yes & Yes & Yes \\
\hline Number of observations & & & & 574 & & & \\
\hline Number of recipients & & & & 51 & & & \\
\hline Number of recipients per donor group & 51 & 51 & 51 & 50 & 51 & 49 & 33 \\
\hline R-Squared & & & & 0.65 & & & \\
\hline
\end{tabular}

Notes:

Estimation technique: OLS with standard errors clustered by recipient country

- Dependent variable: $(\mathrm{log})$ Aid commitments to recipient country, sum 2008-2010

- We report coefficients of the explanatory variables (corresponding $p$-values in parentheses)

In italics: p-values of a Wald test of equal marginal effects of the respective donor (group) compared to India

* $(* *, * *)$ indicates significance at the ten (five, one) percent level 